\title{
Carbonic fluids in the Hamadi gold deposit, Sudan: Origin and contribution to gold mineralization
}

\begin{tabular}{|r|l|}
\hline Journal: & Canadian Journal of Earth Sciences \\
\hline Manuscript ID & cjes-2016-0058.R2 \\
\hline Danuscript Type: & Article \\
\hline Complete List of Authors: & $\begin{array}{l}\text { Cheng, Xihui; University of Science and Technology Beijing, Dept. of } \\
\text { Resources and Engineering } \\
\text { Xu, Jiuhua; University of Science and Technology Beijing, Department of } \\
\text { resources and engineering } \\
\text { Wang, Jianxiong; Wuhan Center of China Geological Survey } \\
\text { Xue, Qingbo; Tianjin North China Geological Exploration Bureau } \\
\text { Zhang, Hui; University of Science and Technology Beijing, Department of } \\
\text { resources and engineering }\end{array}$ \\
\hline Keyword: & $\begin{array}{l}\text { Carbonic fluid inclusions, gold-bearing quartz veins, metamorphic } \\
\text { environment, Hamadi gold deposit, North Sudan }\end{array}$ \\
\hline \multicolumn{2}{|l}{} \\
\hline
\end{tabular}

SCHOLARONE $^{\text {IM }}$

Manuscripts 


\section{Carbonic fluids in the Hamadi gold deposit, Sudan: Origin and contribution to gold mineralization}

Xi-hui Cheng ${ }^{1 *}$, Jiu-hua $\mathrm{Xu}^{1}$, Jian-xiong Wang ${ }^{2}$, Qing-bo Xue ${ }^{3}$, Hui Zhang ${ }^{1}$

1 University of Science and Technology Beijing, Beijing, China, 100083

2 Wuhan Center of China Geological Survey, Wuhan, China, 430205

3 Tianjin North China Geological Exploration Bureau, Tianjin, China, 300170

*Corresponding author: Xi-hui Cheng

University of Science and Technology Beijing, 30 Xueyuan Road, Haidian

District, Beijing 100083 China

Tel: $+\mathbf{8 6} 13269387139$

Email: cheng_xihui@163.com 


\section{Abstract}

The Hamadi gold deposit, located in North Sudan, occurs in the Neoproterozoic metamorphic strata of the Arabian-Nubian Shield (ANS). Two types of gold mineralization can be divided: gold-bearing quartz veins and altered rock ores near ductile shear zones. The gold-bearing quartz veins are composed of white to gray quartz associated with small amounts of pyrite and other polymetallic sulfide minerals. Wallrock alterations mainly include beresitization, epidotization, chloritization, and carbonatization. $\mathrm{CO}_{2}$-rich inclusions are commonly seen in gold-bearing quartz veins and quartz veinlets from gold-bearing altered rocks, which mainly include one-phase carbonic $\left(\mathrm{CO}_{2} \pm \mathrm{CH}_{4} \pm \mathrm{N}_{2}\right)$ inclusions and $\mathrm{CO}_{2}-\mathrm{H}_{2} \mathrm{O}$ inclusions with $\mathrm{CO}_{2} / \mathrm{H}_{2} \mathrm{O}$ volumetric ratios of $30 \sim 80 \%$. Laser Raman analysis does not show the $\mathrm{H}_{2} \mathrm{O}$ peak in carbonic inclusions. For quartz veins, the solid $\mathrm{CO}_{2}$ melting temperatures $(\mathrm{T} m, \mathrm{CO} 2)$ of carbonic inclusions have a narrow range of $-59.6^{\circ} \mathrm{C}$ to $-56.8^{\circ} \mathrm{C}$. Carbonic inclusions also have $\mathrm{T} h, \mathrm{CO} 2$ from $-28.3^{\circ} \mathrm{C}$ to $+23.7^{\circ} \mathrm{C}$, with most of the values clustering between +4.0 and $+20^{\circ} \mathrm{C}$, all of these inclusions homogenized into the liquid $\mathrm{CO}_{2}$ state. The densities range from 0.73 to $1.03 \mathrm{~g} / \mathrm{cm}^{3} . \mathrm{X}_{\mathrm{CH} 4}$ of carbonic fluid inclusions ranges from 0.004 to 0.14 , and with most of $\mathrm{X}_{\mathrm{CH} 4}$ around 0.05 . In $\mathrm{CO}_{2}-\mathrm{H}_{2} \mathrm{O}$ fluid inclusions, Tm, $\mathrm{CO} 2$ values were recorded mostly around $-57.5^{\circ} \mathrm{C}$. The melting temperatures of clathrate are from 3.8 to $8.9^{\circ} \mathrm{C}$. It is suggested that the lowest trapping pressures of $\mathrm{CO}_{2}$ fluids would be $100 \sim 400 \mathrm{MPa}$ based on $\mathrm{T} h, \mathrm{CO} 2$ of $\mathrm{L}_{\mathrm{CO} 2}$ inclusions and $\mathrm{T} h$,tot of paragenetic $\mathrm{L}_{\mathrm{CO} 2}-\mathrm{L}_{\mathrm{H} 2 \mathrm{O}}$ inclusions. For altered rocks, the solid $\mathrm{CO}_{2}$ melting temperatures $(\mathrm{T} m, \mathrm{CO} 2)$ of carbonic inclusions have a narrow range of 
$-58.4 \sim-57.0^{\circ} \mathrm{C}$, whereas the homogenization temperatures $(\mathrm{T} h, \mathrm{CO} 2)$ vary widely $\left(-19^{\circ} \mathrm{C} \sim+29^{\circ} \mathrm{C}\right)$, most of carbonic inclusions and the carbonic phases in the $\mathrm{CO}_{2}-\mathrm{H}_{2} \mathrm{O}$ inclusions are homogenized to liquid $\mathrm{CO}_{2}$ phases, which correspond to the densities being $0.70 \sim 1.00 \mathrm{~g} / \mathrm{cm}^{3}$. Fluid inclusions in a single FIA have narrow $\mathrm{T} m, \mathrm{CO} 2$ and $\mathrm{T} h, \mathrm{CO} 2$ values, but they vary widely in different FIAs and non-FIAs, which indicates that there was a wide range of trapping $P-T$ conditions during the ore-forming process in late retrograde metamorphism after metamorphism peak period. The carbonic inclusions in the Hamadi gold deposit are interpreted to have resulted from unmixing of an originally homogeneous aqueous-carbonic mixture during retrogress metamorphism due to decreasing of $P-T$ conditions. $\mathrm{CO}_{2}$ contributed to gold mineralization by buffering the $\mathrm{pH}$ range and increasing the gold concentration in the fluids.

Keywords: Carbonic fluid inclusions; gold-bearing quartz veins; metamorphic environment; Hamadi gold deposit; North Sudan

\section{Introduction}

Since the term of "orogenic gold deposit" was first used by Bohlke (1982) and comprehensively introduced by Groves et al. (1998), orogenic-type gold deposits have been well documented in ore geology, geochemistry and tectonic setting (Groves et al. 1998; Goldfarb et al. 2005). It is well known that low salinities and $\mathrm{CO}_{2}$-rich fluids are one of the most important characteristics of the orogenic gold deposits (e.g., Groves et al. 1998; Goldfarb et al. 2001; Goldfarb et al. 2005; Phillips et al. 2004; 
Ridley and Diamond 2000). Carbonic fluid inclusions lacking visible $\mathrm{H}_{2} \mathrm{O}$ at room temperatures were found in orogenic gold deposits in last decades, such as the gold mineralization of the Ashanti Belt, Ghana (Schmidt Mumm et al. 1997), the Muruntau gold deposit of Uzbekistan (Graupner et al. 2001; Wilde et al. 2001), the Campbell-Red Lake gold deposit in Canada (Chi et al. 2006), the Carará deposit of Brazil (Klein and Fuzikawa 2010), and the Sarekoubu gold deposit of southern Altay in China (Xu et al. 2005). The source of these carbonic fluid inclusions and their contribution to gold mineralization are still controversial.

The Arabian-Nubian Shield (ANS) hosts a great number of orogenic gold and VMS deposits (Ghebreab et al. 2009; Botros 2002; Tadesse et al. 2003; Schmidt Mumm et al. 1997). The eastern part of ANS has been extensively explored since the 1970s, with numerous discoveries of deposits including gold, silver, copper, molybdenum, and zinc, but the west ANS has received less exploration attention in the last decades (Trench and Groves 2015). The geological characteristics show that there is great potential for the prospecting of gold deposit in the area. Our recent study on the Hamadi gold deposit, which occurs in the Neoproterozoic metamorphic strata of the west ANS, shows that there are numerous carbonic fluid inclusions both in gold-bearing quartz veins and veinlets in altered wall rocks. Where did these carbonic fluids come from and how did they contribute to gold mineralization? These questions remain to be answered for the origin of the Hamadi gold deposit. In this paper, we present fluid inclusion studies on mineralized quartz veins and altered rocks from the Hamadi gold deposit and attempt to illustrate the origin of the carbonic inclusions and 
the contribution of the carbonic fluids to gold mineralization.

\section{Geological Setting}

\subsection{Regional geology}

The Arabian-Nubian Shield (ANS) was an accretion orogenic belt that formed during convergence between the East and West Gondwana land at the end of the Wilson cycle from 900 to $500 \mathrm{Ma}$, which is called the Pan-African orogeny (El-Gaby et al. 1988; Pohl 1988; Stern et al. 1994). The Hamadi gold deposit is located in the Neoproterozoic greenstone belt of the Arabian-Nubian Shield (ANS) in North Sudan, which is formed by crustal growth during the Neoproterozoic Pan-African orogenic period (Fig. 1). It is situated on the splicing structure zone of Kerns (Stern et al. 1994). Four periods of regional magmatic intrusion events can be identified: (1) intermediate-acid magmatic intrusion in Paleoproterozoic; (2) intermediate-acid and ultramafic intrusion during the Neoproterozoic; (3) intermediate-acid magmaic intrusion and eruption during Palaeozoic-Mesozoic; and (4) eruption of basaltic magma during Cenozoic. Gold mineralization in this area is associated with tectonic hydrothermal events caused by three periods of magma activities (El-Gaby et al. 1998; Stern et al. 1994).

There are three periods of regional tectonic events: 1) during the period of the Neoproterozoic, formingtight and overturned folds; 2) during the period of the Palaeozoic to Mesozoic, forming the Bayuda metamorphic core complex, generally manifested as tectonic basins and radial fractures; 3) during the period of the 
Cenozoic, forming a series of N-S tensional fractures (Stern et al. 1994). Dominantly NE- to E-trending relict fold structures are present in North Sudan. Collision-related granulite to amphibolite facies metamorphism in the region occurred between 720 and $700 \mathrm{Ma}$ (Stern et al. 1994). The basement of the Wadi Singeir basin consists of Paleoproterozoic to Mesoproterozoic metamorphic strata, which are mainly composed of granitic gneiss. The overlying strata are composed of Neoproterozoic metasediment and metavolcanic rocks. In addition, there is a large outcrop composed of Cenozoic basalt. In the Arabian-Nubian Shield, gold mineralization is widely associated with post-tectonic granitoid rocks (El-Gaby et al. 1988; Pohl 1988). The majority of gold deposits occur as Au-bearing quartz veins with a polymetallic sulphide assemblage, exhibiting pinch-swell vein textures and showing evidence of multiple stages of mineralization (Hilmy and Osman 1989; Hussein 1990; Harraz and El-Dahhar 1993). $P-T$ conditions at or below greenschist metamorphic boundary favoured establishment of brittle-ductile and brittle structures in which gold deposits were selectively sited (El-Gaby et al. 1988). Formation of gold-bearing silicified shear zones in these shields was likely contemporaneous with greenschist-grade metamorphism and granitoid diapirism (Goldfarb et al. 2005), or as a result of brittle-ductile shearing and folding (e.g., Reinhardt and Davison 1990). Strata in North Sudan mainly consist of medium-low metamorphic grade metasedimentary and metavolcanic rocks, which are equivalent to greenschist facies to epidote-amphibolite facies. Metamorphic rocks of this region suffered from multiple stages deformation and metamorphism (Almond and Shaddad 1984). 


\subsection{Ore deposit geology}

The Hamadi gold deposit, situated on the splicing structure zone of Kerns (Deschamps and Lescuyer 2002), is hosted in plagioclase hornblende gneiss, mica plagioclase gneiss, mica quartz schist, chlorite schist, and hornblende schist of Neoproterozoic metamorphic strata (Fig. 1). Gold reserves were estimated to be 13 tones of Au by Tianjin North China Geological Exploration Bureau during 2006 to 2008, and potential resource was expected to be 65 tones of Au (Yang and Liu 2009). The gold veins at the Hamadi gold deposit are mainly controlled by the shear zone and fold. The vein systems, striking SN and dipping $42^{\circ}-44^{\circ}$ to west, are composed of vein I, vein II. The ore shoots are 100-500 $\mathrm{m}$ in length and 2.5-7.0 $\mathrm{m}$ in width, with 1.0-5.4 $\mathrm{m}$ in thickness. Gold grades in the veins and wall rocks vary significantly along mineralized zones, from 0.73 to $65.54 \mathrm{~g} / \mathrm{t}$ and 0.75 to $21.75 \mathrm{~g} / \mathrm{t}$, respectively. Gold mineralization is mainly controlled by deformation zones which are characterized by silicification, pyritization and sericitization zones in $100 \mathrm{~m}-500 \mathrm{~m}$ width (Fig. 2). Two types of gold mineralization are found in this area, including gold-bearing quartz veins and altered rock ores near ductile shear zones. The gold-bearing quartz veins are composed of white to gray quartz associated with small amounts of pyrite and other polymetallic sulfide minerals, which have variable thickness from $0.3 \mathrm{~m}$ to $8 \mathrm{~m}$. The altered rock ores are mainly characterized by gold-bearing pyritization and carbonatization in biotite-quartz schist, carbonatization in hornblende-quartz schist, and beresitization in mylonitic schist (Fig. 3). 
Sericitization, pyritization, and silicification (beresitization) are intensive in gold mineralization zones, and carbonatization, chloritization, and epidotization are also found of the some portions in mineralizing areas.

Ore minerals in the vein systems mainly include native gold, pyrite, chalcopyrite, and pyrrhotite (Figs. 4A-D). Gangue minerals are dominated by quartz, calcite, garnet, chlorite, and plagioclase. Pyrite is main host mineral of gold, and occurs as disseminated or veinlets in the ores and usually was replaced by chalcopyrite (Figs. 4E-I). Pyrite in the alteration zone occurs dominantly as veinlet and disseminated (Fig. 3A and 3B). In mylonitic schist, pyrite metacrysts may occur as rotated grains (Fig. 3C) or as stretched grains (Fig. 3D). The ore shoots occur in places where both pyrite and quartz veins are developed. Carbonatization is also related to gold mineralization, and is characterized by disseminated calcite replacing earlier generation of minerals or calcite-quartz veinlets. Gold occurs mainly in the tiny fissures within quartz (Fig. 4E), or as inclusions within coarse pyrite grains (Fig. 4F). Gold grains occur mainly as fissure-filling gold and inclusive gold in tiny fissures of pyrite, marcasite and quartz, or as inclusions in pyrite crystals. The size of gold grains range from 0.01 to $0.40 \mathrm{~mm}$ (Li and $\mathrm{Hu} 2012$ ).

On the basis of field geology and ore assemblages, three hydrothermal-structural stages can be distinguished: (I) A disseminated pyrite stage, characterized by disseminated pyrite within altered wall rocks; (II) A pyrite-quartz vein stage, characterized by small amounts of disseminated coarse pyrite grains associated with large portion of white quartz in veins crosscut by polymetallic sulfides; (III) A 
polymetallic sulfide stage, marked by metal sulfides including chalcopyrite, sphalerite, galena, and pyrrhotite. Stages I and II are the main gold mineralization stages.

\section{Fluid Inclusion Study}

\subsection{Sampling and analytical techniques}

More than twenty samples of pyrite-quartz veins and altered rocks from outcrops and drill cores were collected to be made into doubly polished thin sections for fluid inclusion studies. Five samples of quartz veins and four samples of altered rock ores in which fluid inclusions are abundant were selected for microthermometry.

Fluid inclusion microthermometry was done at the fluid inclusions laboratory of University of Science and Technology Beijing using a Linkam THMS600 heating-freezing stage (from $-196^{\circ} \mathrm{C}$ to $550^{\circ} \mathrm{C}$ ). During the microthermometric work several runs have been undertaken down to the lowest limit of temperature of the heating freezing stage, in order to detect the presence of $\mathrm{CH}_{4}$ and/or $\mathrm{N}_{2}$. However, all inclusions froze between -100 and $-120{ }^{\circ} \mathrm{C}$, and no further freezing event was observed below these temperatures, indicating that $\mathrm{CH}_{4}$ and/or $\mathrm{N}_{2}$ are not present in significant amounts. The estimated accuracy for temperatures is $+/-0.1{ }^{\circ} \mathrm{C}$ for $\mathrm{CO}_{2}$ solid melting points, $\mathrm{CO}_{2}$ partial homogenization temperatures, clathrate melting temperatures and ice melting temperatures, and $\pm 1{ }^{\circ} \mathrm{C}$ for total homogenization temperatures. The fluid inclusion assemblage (FIA) method (Goldstein and Reynolds 1994; Chi and Lu 2008) was applied in petrographic study and microthermometry data analysis. Fluid Inclusion Assemblage (FIA) refers to discriminate a group of 
petrographically associated fluid inclusions (Goldstein and Reynolds 1994) that are cogenetic, forming at the same time and from the same fluid. Fluid inclusions that occur within healed tiny fissures or within growth zones of host mineral may be identified as FIA (Chi and Lu 2008). We also use abbreviation "non-FIA" to represent those fluid inclusions which occur as isolated and randomly distributed, but not in healed microfractures. Salinities of aqueous FIs were estimated using the reference data of Bodnar (1993) for the $\mathrm{NaCl}-\mathrm{H}_{2} \mathrm{O}$ system. Salinities of $\mathrm{CO}_{2}$-rich FIs were calculated using the equations of Collins (1979).

Raman analyses of fluid inclusions were undertaken using a LABHR-VISLabRAM HR800 Raman spectrometer at the Fluid Inclusion Laboratory of the Institute of Geology and Geophysics, Chinese Academy of Sciences (IGG-CAS). The wave length was $532 \mathrm{~nm}$ for the argon ion laser.

\subsection{Fluid inclusion petrography}

Fluid inclusions suitable for microthermometric study were found mostly in quartz grains from the main stages of mineralization in the Hamadi gold deposit. According to their nature, phases at room temperature and phase transitions during heating and cooling, and laser Raman spectroscopy, three types of fluid inclusions from the Hamadi gold deposit can be distinguished at room temperatures, including carbonic inclusions (C) (one-phase of $\mathrm{CO}_{2}$ with small amounts of $\mathrm{CH}_{4}$ or $\mathrm{N}_{2}$ ), $\mathrm{CO}_{2}-\mathrm{H}_{2} \mathrm{O}$ inclusions (CW) (two phases composed of $\mathrm{H}_{2} \mathrm{O}$-rich liquid phase and $\mathrm{CO}_{2}$-rich liquid (or gas) phase, with $30 \sim 80 \%$ of $\mathrm{CO}_{2} / \mathrm{H}_{2} \mathrm{O}$ ratios) (Figs. $5 \mathrm{~A}, 5 \mathrm{~B}, 5 \mathrm{C}$ ), and aqueous 
inclusions (W) (two phases composed of water and vapor phases).

\subsubsection{Carbonic inclusions (Type C)}

Carbonic fluid inclusions are non-aqueous fluid inclusions described by the system $\mathrm{CO}_{2}-\mathrm{CH}_{4}-\mathrm{N}_{2}$ (Van den Kerkhof and Thiery 2001). Fluid inclusions in gold-bearing veins from the Hamadi gold deposit are characterized by the abundance of carbonic inclusions including pure $\mathrm{CO}_{2}$ and mostly $\mathrm{CO}_{2}-\mathrm{CH}_{4}$ inclusions. Carbonic inclusions occupy more than $90 \%$ of the total fluid inclusions observed in auriferous quartz veins

(Fig. 6). They generally occur in monophase, only composed of liquid $\mathrm{CO}_{2}$ at room temperature, or consist of a liquid $\mathrm{CO}_{2}$ phase and a vapour $\mathrm{CO}_{2}$ bubble, commonly in sizes of several microns and up to tens of microns. Most of the carbonic fluid inclusions occur as isolated or randomly distributed ones (Figs. 5D, 5E), indicating that these inclusions are primary or pseudo-secondary. Fluid inclusions that occur within healed microfractures (Figs. 5F, 5G) or within growth zones of host mineral can be easily identified as FIA. In many cases, fluid inclusion within individual FIAs show similar microthermometric attributes, suggesting that these inclusions were entrapped as a homogeneous phase. These fluid inclusions occur as FIAs in quartz of gold-bearing veins, which can be observed in two groups: (1) primary (or pseudo-secondary) carbonic fluid inclusions mainly in the gold-bearing veins of the Hamadi gold deposit; which are sometimes associated with $\mathrm{CO}_{2}-\mathrm{H}_{2} \mathrm{O}$ inclusions. Group 1 fluid inclusions are either rounded or negative crystal shapes whose occurrence is limited to internal fissure planes of quartz crystals, and (2) secondary carbonic fluid inclusion in fissures formed after the growth of the quartz crystals, 
commonly in sizes of several microns, generally in elongated quartz crystal fragments where fluid inclusions are perpendicular to the direction of foliation (or schistosity) in quartz veins. Secondary carbonic fluid inclusion distributed as oriented healed fractures, and generally cut across the boundaries of the quartz grains and truncate.

\subsection{2. $\mathrm{CO}_{2}-\mathrm{H}_{2} \mathrm{O}$ inclusions (Type $\mathrm{CW}$ )}

They appear irregular, ellipsoid and negative quartz crystal in shape, 5 to $20 \mu \mathrm{m}$ in size, isolated or as clusters in occurrence. $\mathrm{CO}_{2}-\mathrm{H}_{2} \mathrm{O}$ inclusions are composed of a liquid $\mathrm{CO}_{2}$ phase and an aqueous phase at room temperatures and $30 \sim 80 \% \mathrm{CO}_{2} / \mathrm{H}_{2} \mathrm{O}$ ratios. These inclusions occur occasionally in the main stage of gold mineralization. Some $\mathrm{CO}_{2}-\mathrm{H}_{2} \mathrm{O}$ inclusions show three phases: a $\mathrm{CO}_{2}$ liquid phase, a $\mathrm{CO}_{2}$ vapor phase, and an aqueous phase at room temperatures. The $\mathrm{CW}$ type fluid inclusions are not abundant in main stages of mineralization and can be further divided into two subtypes. The type CW1 fluid inclusions contain more $\mathrm{CO}_{2}$ than $\mathrm{H}_{2} \mathrm{O}$ (Fig. 5I) while the type CW2 inclusions have more $\mathrm{H}_{2} \mathrm{O}$ than $\mathrm{CO}_{2}$ (Fig. 5I). Most of the $\mathrm{CO}_{2}-\mathrm{H}_{2} \mathrm{O}$ inclusions occur as randomly distributed or isolated inclusions, indicating primary origin, and sometimes are associated with carbonic inclusions (Figs. 5H, 5I).

\subsubsection{Aqueous inclusions (Type W)}

The $\mathrm{W}$ type inclusions consist of aqueous vapor and liquid at room temperature. Secondary aqueous inclusions can be found in the latest fissures. They occur along the tiny fractures cutting quartz grains. Salt-aqueous inclusions occur as FIAs in the quartz veins of the Hamadi deposit. These inclusions form only a small percentage of all fluid inclusions in study altered rock samples. Aqueous inclusions associated with 
a few $\mathrm{CO}_{2}-\mathrm{H}_{2} \mathrm{O}$ inclusions. Their sizes range from 3 to $8 \mu \mathrm{m}$ and the vapor phase account for 5-20 volume $\%$.

\subsection{Fluid inclusion microthermometry}

\subsubsection{Microthermometry for quartz veins}

More than four fluid inclusion assemblages (FIA) can be identified in some samples of vein quartz (Figs. 5D, 5E). Microthermometric measurements on 28 FIAs and 309 non-FIAs were performed. The microthermometric data are summarized in Table 1 and Table 2. The microthermometric data and behaviors of fluid inclusions during microthermometry are described as follows.

(1) Carbonic inclusions (type $\mathrm{C})$. A bubble $\left(\mathrm{V}_{\mathrm{CO} 2}\right)$ appears in monophase $\mathrm{CO}_{2}$ when they are cooled down from room temperatures (down to $-30^{\circ} \mathrm{C}$ ), indicating that the inclusions are composed of liquid $\mathrm{CO}_{2}$ at room temperature. The liquid $\mathrm{CO}_{2}$ freeze into solid $\mathrm{CO}_{2}$ after they are continually cooled down to $-95^{\circ} \mathrm{C}$. The melting of solid $\mathrm{CO}_{2}$ happens at above $-60^{\circ} \mathrm{C}$ after heating from these low temperatures. The melting temperatures of solid $\mathrm{CO}_{2}(\mathrm{~T} m, \mathrm{CO} 2)$ range in a very narrow interval between $-56.6^{\circ} \mathrm{C}$ and $-59.6^{\circ} \mathrm{C}$, with a sharp peak being observed at $-57.0^{\circ} \mathrm{C}$, which indicates that $\mathrm{CO}_{2}$ are dominant and other gases such as $\mathrm{CH}_{4}$ and $\mathrm{N}_{2}$ are subordinate. The solid $\mathrm{CO}_{2}$ melting temperatures $(\mathrm{T} m, \mathrm{CO} 2)$ of carbonic inclusions range from $-59.6^{\circ} \mathrm{C}$ to $-56.8^{\circ} \mathrm{C}$ for 23 different FIAs, and from $-59.6^{\circ} \mathrm{C}$ to $-56.9^{\circ} \mathrm{C}$ for 122 non-FIA inclusions (Fig. 7A). The result indicates that $\mathrm{CO}_{2}$ is dominant at the main mineralization stages of hydrothermal event, with small amounts of other volatiles like $\mathrm{CH}_{4}$ and $\mathrm{N}_{2}$ (Roedder 
1984). The homogenization temperatures of $(\mathrm{T} h, \mathrm{CO} 2)$ of carbonic inclusions, all into the liquid phase, range widely from $-28.3^{\circ} \mathrm{C}$ to $+23.7^{\circ} \mathrm{C}$ (23 FIAs), and from $-7.4^{\circ} \mathrm{C}$ to $+20.8^{\circ} \mathrm{C}$ (122 non-FIA inclusions) (Fig. 7B). The $\mathrm{CO}_{2}$ fluid densities range from 0.73 to $1.03 \mathrm{~g} / \mathrm{cm}^{3}$, which were calculated by using $\rho-\mathrm{T}_{\mathrm{h}}-\mathrm{X}_{\mathrm{CH} 4}$ phase diagram of Swanenberg (1979) (Table 1 and Table 2). All the FIAs show a considerable narrow range of homogenization temperatures. For example, type carbonic fluid inclusions within a single FIA have a very narrow ranges of $\mathrm{T} m, \mathrm{CO} 2$ and $\mathrm{T} h, \mathrm{CO} 2$, such as from -57.6 to $-57.2^{\circ} \mathrm{C}(\mathrm{T} m, \mathrm{CO} 2)$ and from 10.2 to $11.6^{\circ} \mathrm{C}(\mathrm{T} h, \mathrm{CO} 2$ homogenized to liquid $\mathrm{CO}_{2}$ phase) in sample HMD202-d (Fig. 8). The estimated $\mathrm{CO}_{2}$ densities of carbonic inclusions are from 0.80 to $0.88 \mathrm{~g} / \mathrm{cm}^{3}$.

(2) $\mathrm{CO}_{2}-\mathrm{H}_{2} \mathrm{O}$ inclusions (type $\mathrm{CW}$ ). The cooling and heating behavior of $\mathrm{CO}_{2}$ phases in $\mathrm{CO}_{2}-\mathrm{H}_{2} \mathrm{O}$ inclusions is similar to those of carbonic $\mathrm{CO}_{2}$ inclusions. The $\mathrm{T} m, \mathrm{CO} 2$ of $\mathrm{CO}_{2}-\mathrm{H}_{2} \mathrm{O}$ inclusions occurring in FIAs range from $-57.9^{\circ} \mathrm{C}$ to $-56.8^{\circ} \mathrm{C}$ for 5 different FIAs, and from $-57.8^{\circ} \mathrm{C}$ to $-56.9^{\circ} \mathrm{C}$ for isolated or randomly distributed $\mathrm{CO}_{2}-\mathrm{H}_{2} \mathrm{O}$ inclusions for 47 non-FIA inclusions (Fig. 7C). The $\mathrm{CO}_{2}$ partial homogenization temperatures $(\mathrm{T} h, \mathrm{CO} 2)$ range from $-9.5^{\circ} \mathrm{C}$ to $27.2^{\circ} \mathrm{C}$ for 5 different FIAs, and generally homogenize to liquid. The $\mathrm{CO}_{2}$ partial homogenization temperatures $(\mathrm{T} h, \mathrm{CO} 2)$ range from $-10.1{ }^{\circ} \mathrm{C}$ to $28.8^{\circ} \mathrm{C}$ for 47 non-FIA inclusions, and generally homogenize to liquid. (Fig. 7D). Most of the $\mathrm{CO}_{2}-\mathrm{H}_{2} \mathrm{O}$ inclusions with high $\mathrm{CO}_{2} / \mathrm{H}_{2} \mathrm{O}$ volume ratios were decrepitated before final homogenization, only a few total homogenization temperatures $\left(\mathrm{T} h h_{\text {tot }}\right)$ of these inclusions were obtained. Some $\mathrm{CO}_{2}-\mathrm{H}_{2} \mathrm{O}$ inclusions homogenized into the liquid $\mathrm{CO}_{2}$ state, and few inclusions 
homogenized into the gas $\mathrm{CO}_{2}$, which are corresponding to the densities being $0.62 \sim 0.96 \mathrm{~g} / \mathrm{cm}^{3}$ calculated by using $\rho-\mathrm{T}_{\mathrm{h}}$ phase diagram of Shepherd et al. (1985). It seems that there are no obvious differences between FIAs and non-FIA inclusions from $\mathrm{T} m, \mathrm{CO} 2$ and $\mathrm{T} h, \mathrm{CO} 2$, but the total homogenization temperatures $(\mathrm{T} h$, tot $)$ for $\mathrm{CO}_{2}-\mathrm{H}_{2} \mathrm{O}$ inclusions are different. The values of $\mathrm{T} h$, tot for FIA range from $264^{\circ} \mathrm{C}$ to $301^{\circ} \mathrm{C}$, whereas those of non-FIA range from $243^{\circ} \mathrm{C}$ to $398^{\circ} \mathrm{C}$ (Table 2; Fig. 7E). For example, $\mathrm{CO}_{2}-\mathrm{H}_{2} \mathrm{O}$ inclusions within a single FIA have a very narrow ranges of $\mathrm{T} m, \mathrm{CO} 2, \mathrm{~T} h, \mathrm{CO} 2$ and $\mathrm{T} h$, tot such as from -56.8 to $-57.0^{\circ} \mathrm{C}(\mathrm{T} m, \mathrm{CO})$, from 26.8 to $27.2^{\circ} \mathrm{C}$ (Th, $\mathrm{CO} 2$ homogenized to liquid $\mathrm{CO}_{2}$ phase) and from 301 to $307^{\circ} \mathrm{C}$ ( $\mathrm{T} h$,tot $)$ in sample HMD203-a. It is noted that the values of $h_{\text {,tot }}$ of FIAs are lower than those of non-FIA inclusions, indicating that those FIAs might represent later events. The clathrates melted ranges from $3.8^{\circ} \mathrm{C}$ to $8.9^{\circ} \mathrm{C}$, indicating salinities around 2.2 to 10.7 wt.\% $\mathrm{NaCl}$ equiv.(Fig. 7F).

\subsubsection{Microthermometry for altered rocks}

(1) Carbonic fluid inclusions in quartz veinlets from gold-bearing altered rocks were also studied for microthermometry (Table 3). Primary carbonic inclusions in quartz veinlets either occur as isolated or as randomly distributed inclusions, whereas secondary carbonic inclusions occur in microfractures. The solid $\mathrm{CO}_{2}$ melting temperatures $(\mathrm{T} m, \mathrm{CO} 2)$ of carbonic inclusions have a narrow range of $-58.4 \sim-57.0^{\circ} \mathrm{C}$, whereas the homogenization temperatures $(\mathrm{T} h, \mathrm{CO} 2)$ vary widely $\left(-19^{\circ} \mathrm{C} \sim+29^{\circ} \mathrm{C}\right)$, which correspond to the densities being $0.70 \sim 1.00 \mathrm{~g} / \mathrm{cm}^{3}$ calculated by using $\rho-\mathrm{T}_{\mathrm{h}}-\mathrm{X}_{\mathrm{CH} 4}$ phase diagram of Swanenberg (1979). 
(2) Aqueous inclusions. Aqueous inclusions (L-V) have $-5.2 \sim-0.9^{\circ} \mathrm{C}$ of ice melting temperature, with the salinities being $1.57 \% \sim 8.14 \% \mathrm{NaCl}$ equiv. and the densities being $0.85 \sim 1.01 \mathrm{~g} / \mathrm{cm}^{3}$ (density was calculated using $\mathrm{T}-\mathrm{W}-\rho$ phase diagram from Bodnar 1983). Most of inclusions show total homogenization temperatures $\left(\mathrm{T}_{\mathrm{h}, \text { total }}\right)\left(109 \sim 227^{\circ} \mathrm{C}\right)$.

\subsection{Laser Raman spectroscopy}

The gas compositions of individual carbonic fluid inclusions and carbonic-aqueous inclusions from five doubly polished sections were analyzed with laser Raman spectrometry (Fig. 9). Laser Raman spectroscopy reveals that the carbonic fluid inclusions contain dominantly $\mathrm{CO}_{2}$ and little and variable amounts of $\mathrm{CH}_{4}$. This is consistent with the triple point of $\mathrm{CO}_{2}$ phase being slightly lower than $-56.6^{\circ} \mathrm{C}$. Laser Raman analysis does not show the $\mathrm{H}_{2} \mathrm{O}$ peak in carbonic inclusions.

\subsection{Summary of published stable isotope data}

$\mathrm{Li}$ and $\mathrm{Hu}$ (2012) conducted a reconnaissance stable isotope study in gold-bearing quartz veins from the Hamadi gold deposit, and compared them to the fields of metamorphic and magmatic fluids compiled by Taylor (1997), in order to trace possible sources for the ore-bearing fluid. The $\delta^{18} \mathrm{O}_{\mathrm{V}-\mathrm{SMOW}}$ values of quartz range from $+9.8 \%$ to $+11.1 \%$ in the gold-bearing quartz veins, and the $\delta \mathrm{D}_{\mathrm{V}-\mathrm{SMOW}}$ values of fluid inclusions range from $-49 \%$ o to $-67 \%$. The results were normalized with V-SMOW standards and the precisions were $\pm 2 \%$ and $\pm 0.2 \%$ for $\delta \mathrm{D}$ and $\delta^{18} \mathrm{O}$, 
respectively. The oxygen isotope ratios of water in equilibrium with quartz were calculated by the equation $1000 \ln \alpha_{\text {quartz-H2O }}=3.38 \times 10^{6} \mathrm{~T}^{-2}-3.40$ (Clayton et al. 1972). The average temperature of $310^{\circ} \mathrm{C}$ (from this study) is adopted to calculate the average $\delta^{18} \mathrm{O}$ values of the fluids. As a result, the quartz from the Au-bearing ores shows the $\delta^{18} \mathrm{O}_{\mathrm{H} 2 \mathrm{O}}$ values ranging from $3.88 \%$ to $4.73 \%$.

Sulfur isotopic compositions of sulfide minerals (pyrite and arsenopyrite) in the Hamadi gold deposit have been measured ( $\mathrm{Li}$ and $\mathrm{Hu} 2012$ ). The $\delta^{34} \mathrm{~S}_{\mathrm{CDT}}$ values of pyrite vary from $-2.6 \%$ to $-4.6 \%$. The $\delta^{34} \mathrm{~S}_{\mathrm{CDT}}$ value of arsenopyrite is $-4.3 \%$.

\section{Discussion}

\subsection{Sources of ore-forming fluids and materials}

The quartz from the Au-bearing ores shows the $\delta^{18} \mathrm{O}_{\mathrm{H} 2 \mathrm{O}}$ values ranging from $3.88 \%$ o to $4.73 \%$, and the corresponding $\delta \mathrm{D}_{\mathrm{H} 2 \mathrm{O}}$ values of fluid vary from $-49 \%$ o to $-67 \%$. The oxygen and hydrogen isotope values lie within the metamorphic sources for the water in the gold-bearing quartz veins at Hamadi gold deposit, which suggests that metamorphic fluids may have a major source of the ore-forming fluids (Fig. 10). The fluid inclusion homogenization temperature and salinity are also consistent with a metamorphic fluid source (Fig. 11). In particular, the generally low salinities, $\mathrm{CO}_{2}$-rich characteristics and the absence of any solid bearing fluid inclusions clearly show features of metamorphic water identified in most orogenic-type deposits (Chen et al. 2007). From the data presented above, we suggest that the gold veins at Hamadi were deposited at intermediate temperatures between 243 and $398^{\circ} \mathrm{C}$ from a 
$\mathrm{H}_{2} \mathrm{O}-\mathrm{CO}_{2}-\mathrm{NaCl}$ fluid system with low-moderate salinities of $2.2 \sim 10.7 \mathrm{wt} . \% \mathrm{NaCl}$ equiv. This mineralizing fluid shares many similarities with typical orogenic gold systems although with relatively higher salinities (mostly $<12$ wt. $\% \mathrm{NaCl}$ equiv. for the orogenic gold deposit, Fig. 12; Goldfarb et al. 2005).

The $\delta^{34} \mathrm{~S}$ values of sulfides from pyrite and arsenopyrite have a narrow range of $-2.6 \%$ to $-4.6 \%$, with an average of $-3.6 \%$. They are comparable to those of many orogenic gold lode deposits, such as Bendigo ( $-7.4 \%$ to $8.1 \%$; Jia et al. 2001), Sawayaerdun (-1.8\%o to $0.9 \%$; Chen et al. 2012$)$, and Juneau $(-17.8 \%$ o to $1.2 \%$; Goldfarb et al. 1991) in which ore-forming fluids were inferred to be metamorphic in origin. The narrow range of sulfide $\delta^{34} \mathrm{~S}$ values indicate that the sulfur in the Hamadi gold deposit was derived from a single source, which may have a connection with the mantle. Ore mineral assemblages mainly include pyrite, pyrrhotite and arsenopyrite. The sulfur belongs to low valence state within these minerals, which indicates that the oxygen fugacity is low during the formation of the sulfide minerals.

\subsection{Mineralizing $P$-T conditions from extremely $\mathrm{CO}_{2}$-rich fluids}

The pressure-temperature trapping conditions of fluid inclusions can be constructed from the microthermometric data, in combination with mineral phase equilibrium, and geological evidence. It is clear that primary fluid inclusions in the Hamadi gold deposit are predominantly carbonic inclusions with high densities, some of which are higher than $1.0 \mathrm{~g} / \mathrm{cm}^{3}$. Meanwhile, some carbonic fluid inclusions occur as FIAs in quartz of gold-bearing veins, indicating the later tectonic hydrothermal events after host quartz formed. 
Since no $\mathrm{N}_{2}$ was found in Laser Raman spectroscopy, only the $\mathrm{X}_{\mathrm{CH} 4}$ values of carbonic phases were calculated according to $\mathrm{T} m, \mathrm{CO} 2$ and $\mathrm{T} h, \mathrm{CO} 2$ of carbonic and $\mathrm{CO}_{2}-\mathrm{H}_{2} \mathrm{O}$ inclusions by using the V-X phase diagram (Thiéry et al. 1994; Van den Kerkhof and Thiéry 2001). As shown in Fig. 13, $\mathrm{X}_{\mathrm{CH} 4}$ of carbonic fluid inclusions at the Hamadi gold deposit may be from 0.004 to 0.14 , with most of which are around 0.05. Considering mixing with a little water, we presume that $270 \sim 390^{\circ} \mathrm{C}$, the lower homogenization temperatures of coexisting $\mathrm{L}_{\mathrm{CO}_{2}}-\mathrm{L}_{\mathrm{H} 2 \mathrm{O}}$ inclusions, were the lowest trapping temperatures of $\mathrm{CO}_{2}$ fluids. Thus, we roughly estimate the trapping pressures of $\mathrm{CO}_{2}$-rich fluid inclusions in the gold-bearing quartz veins. It is suggested that the lowest trapping pressures of $\mathrm{CO}_{2}$ fluids would be $100 \sim 400 \mathrm{MPa}$ based on $\mathrm{T} h, \mathrm{CO} 2$ of $\mathrm{L}_{\mathrm{CO} 2}$ inclusions and $\mathrm{T} h$,tot of paragenetic $\mathrm{L}_{\mathrm{CO} 2}-\mathrm{L}_{\mathrm{H} 2 \mathrm{O}}$ inclusions at high temperature and pressure of Van den Kerkhof and Thiéry (2001). As shown in Fig. 14, the trapping temperatures $\left(270 \sim 390^{\circ} \mathrm{C}\right)$ and the pressures $(100 \sim 400 \mathrm{MPa})$ were lower than the metamorphic P-T conditions of green schist-facies. These are similar to the Atud gold deposit, located in neighbouring Egypt, which was inferred to have formed over a temperature range of $270 \sim 430^{\circ} \mathrm{C}$ and pressures of $160 \sim 272 \mathrm{MPa}(6 \sim 11 \mathrm{~km}$ depths $)$ (Harraz 2002), and was related to fluid phase separation, sulphidization and carbonatization of host dioritic rocks. These P-T conditions show that the gold mineralization occurred in the late retrograde metamorphism after peak metamorphism.

\subsection{Origin of carbonic fluid inclusions in the Hamadi gold deposit}


The origin of the characteristic $\mathrm{CO}_{2}-\mathrm{CH}_{4}$ fluids in orogenic gold deposits is still controversial (e.g., Ridley and Diamond 2000; Goldfarb et al. 2005; Hrstka et al. 2011). In addition, the presence of variable amounts of non-aqueous volatiles, such as $\mathrm{CH}_{4}-\mathrm{N}_{2}$ and their fraction variations (e.g. $\mathrm{CH}_{4}$ and $\mathrm{N}_{2}$ ), has also been reported (Fu et al. 2014). These non-aqueous volatiles were formed locally by the interaction of mixed $\mathrm{CO}_{2}$ and magmatic fluid during the emplacement of post-orogenic intrusions (Fu et al. 2014). Fluid inclusions in gold-bearing veins and altered rocks from the Hamadi gold deposit are characterized by $\mathrm{CO}_{2}$-rich inclusions, including carbonic inclusions and $\mathrm{CO}_{2}-\mathrm{H}_{2} \mathrm{O}$ inclusions, whereas aqueous inclusions are rare. These carbonic inclusions seem to have a close relationship with gold mineralization during the post-collision orogeny process of 600 to $550 \mathrm{Ma}$ in ANS. However, where the $\mathrm{CO}_{2}$-rich fluids come from and how these fluids contributed to gold mineralization are still unclear.

The source of $\mathrm{CO}_{2}$ in gold deposits in metamorphic terranes has usually been considered as relics of mantle and/or lower crustal (magmatic and/or metamorphic) fluids (e.g., Phillips and Powell 1993; Klemd and Hirdes 1997; Schmidt Mumm et al. 1997; Lowenstern 2001) that might have been transported to higher levels in the crust during magma ascent (Xavier and Foster 1999) and/or channeled along major structures (Chi et al. 2009). Devolatilisation of supracrustal sequences during prograde metamorphism is the more accepted hypothesis for the origin of $\mathrm{CO}_{2}$ in this type of deposits (Phillips and Powell 1993; Kerrick and Caldera 1998). Alternatively, $\mathrm{CO}_{2}$-dominated fluids may exsolve from felsic magmas formed at depths greater than 
$5 \mathrm{~km}$ in the crust; they are a typical feature of intrusion-related deposits (Baker 2002). Furthermore, these fluids are also associated with granulite facies metamorphism (Santosh et al. 1991; Wilmart et al. 1991). Schimdt Mumm et al. (1997) proposed that the gold mineralization of the Ashanti belt formed from gas- or volatile-rich, nearly water free $\left(\mathrm{CO}_{2}>>\mathrm{H}_{2} \mathrm{O}\right)$ hydrothermal systems. The extent of this event suggests that it is related to regional crustal processes. A crustal origin of the mineralizing fluids is also favoured by OberthuÈr et al. (1996) based on extensive stable isotope studies. However, this conclusion was challenged by Klemd (1998). With decreasing temperatures during ductile deformation $\mathrm{H}_{2} \mathrm{O}$ was almost completely removed, since $\mathrm{H}_{2} \mathrm{O}$, due to a lower dihedral angle $\left(<60^{\circ}\right)$ at low temperatures $\left(<450^{\circ} \mathrm{C}\right.$ at $\left.4 \mathrm{kbar}\right)$, is more mobile along quartz-quartz grain boundaries than $\mathrm{CO}_{2}$ (Holness 1993).

The degree of consistency of microthermometric data of fluid inclusions within such FIAs provides a measure of the degree of modification of the inclusions after entrapment. In our study of the Hamadi gold deposit, the homogenization temperatures of $\mathrm{CO}_{2}$ phases $\left(\mathrm{T} h, \mathrm{CO}_{2}\right)$ are highly variable among different FIAs, but show a relatively narrow range within individual FIAs. We also summarize the microthermometry data of fluid inclusions from the representative orogenic gold deposits in the world, which are characterized by $\mathrm{H}_{2} \mathrm{O}$-poor, $\mathrm{CO}_{2}$-dominated, and compare them with those from the Hamadi gold deposit (Table 4). The results illustrate that there are similarities of fluid inclusions among the Hamadi deposit and other orogenic gold deposits in the world. Meanwhile, we put forward several key questions in this paper concerning: (1) whether host minerals of carbonic fluid 
inclusions suffer from the influence of ductile deformation; (2) whether gold-bearing lodes are have close relationship with the strong chloritization, sericitization and epidotization. Fluid inclusions within a single FIA should have the same homogenization temperature if they have not been modified after entrapment (Goldstein and Reynolds 1994), excluding heterogeneous trapping. If fluid inclusions in a FIA are subjected to modification after entrapment, their specific volumes will be changed to variable degrees depending on the size and shape of individual inclusions (Bodnar 2003), which will be reflected by the variation of homogenization temperatures of fluid inclusions within the FIA. Our study shows that most $\mathrm{T} h, \mathrm{CO}_{2}$ of carbonic inclusions within a single FIA from the Hamadi gold deposit have a narrow range of (Table 1), which means that they have not been modified after entrapment if they were trapped from a single water-free carbonic fluid. However, different FIAs have variable ranges of $\mathrm{T} h, \mathrm{CO} 2$, especially for the sample HMD201 which have very low $\mathrm{Th}, \mathrm{CO} 2\left(-28.3 \sim-18.0^{\circ} \mathrm{C}\right)$ in some FIA, indicating that carbonic fluids had higher densities and more complicated components (such as much high $\mathrm{CH}_{4}$ ) in the late stage than in the early. Carbonic inclusions occur as secondary FIAs within quartz veins in the Hamadi gold deposit, whereas they may also occur as primary inclusions in quartz veins, and are associated with $\mathrm{CO}_{2}-\mathrm{H}_{2} \mathrm{O}$ fluid inclusions. From these petrographic relationships, we can deduce that the fluids in the Hamadi deposit were originally $\mathrm{CO}_{2}-\mathrm{H}_{2} \mathrm{O}$ fluids during the formation of quartz veins.

Chi et al. (2006) studied the origin of $\mathrm{CO}_{2}$-only fluid inclusions in the Campbell-Red Lake gold deposit, and put forward a question that whether the 
carbonic inclusions were originally entrapped from water-free carbonic fluids, or trapped from $\mathrm{CO}_{2}-\mathrm{H}_{2} \mathrm{O}$ fluids that experienced water loss during wall rock alteration. Similar questions, such as the origin of $\mathrm{CO}_{2}$-only fluid inclusions, have been asked and discussed in studies of the other gold deposits dominated by carbonic inclusions (e.g., Garba and Akande 1992; Schmidt-Mumm et al. 1997, 1998; Klemd 1998; Xavier and Foster 1999; Wille and Klemd 2004). For the Hamadi gold deposit, carbonic fluid inclusions are so abundant but lack of simultaneous aqueous inclusions that it is hard to believe that $\mathrm{CO}_{2}$ came from a phase separation from an initial $\mathrm{CO}_{2}-\mathrm{H}_{2} \mathrm{O}$ fluid. However, $\mathrm{Li}$ and $\mathrm{Hu}$ (2012) have measured the $\mathrm{H}-\mathrm{O}$ isotopic compositions of fluid inclusions in gold-bearing quartz veins from the Hamadi gold deposit, and result showed the existence of water in the fluid inclusions. Wall rock alterations, including sericitization, chloritization and epidotization are fairly well developed, which illustrated that $\mathrm{H}_{2} \mathrm{O}$ took part in the wall rock alteration and $\mathrm{H}_{2} \mathrm{O}$ may have been consumed in hydrothermal alteration. The deformation of gold-bearing quartz vein is weak, and many carbonic fluid inclusions are randomly distributed or isolated and keep very complete fluid inclusions shape (Fig. 5), which is difficult to explain if the host mineral's deformation caused the preferential leakage of water from $\mathrm{CO}_{2}-\mathrm{H}_{2} \mathrm{O}$ salt fluid inclusions under retrograde greenschist-facies condition. However, some of the carbonic inclusions occur as secondary FIAs within quartz veins, which may be due to the preferential leakage of water from $\mathrm{CO}_{2}-\mathrm{H}_{2} \mathrm{O}$-salt fluid inclusions.

Therefore, the source of carbonic fluid inclusions in the Hamadi gold deposit could 
be explained according to what has been discussed above as follows: the $\mathrm{CO}_{2}-\mathrm{H}_{2} \mathrm{O}$ fluids in relation to granulite or amphibolite facies were derived from the deep crust in the process of regional metamorphism. Unmixing took place at relatively high levels of the crust because of the P-T condition decline during the retrograde metamorphism and gold mineralization (Chi et al. 2006). Water took part in the wall rock alteration, which was depleted in the process of hydrothermal alteration, and then carbonic components were significantly enriched relative to $\mathrm{H}_{2} \mathrm{O}$, which lead to the decrease of $\mathrm{SiO}_{2}$ solubility. Eventually, quartz veins are formed in fractures, and the rich- $\mathrm{CO}_{2}$ fluid was trapped in the quartz vein.

\subsection{The contribution of carbonic fluids to gold mineralization}

Deformation and metamorphism might have caused remobilization and enrichment of the ore elements (Marshall and Gilligan 1987) since primary ores were modified to mineralized tectonite to varying degrees or even to mineralized mylonite ( $\mathrm{Gu}$ et al. 2007). Despite the ubiquitous association of $\mathrm{CO}_{2}$ with hydrothermal ore deposits, little is known about the role of $\mathrm{CO}_{2}$ as a ligand or its direct participation in ore formation. Few studies provide any indication of metal mobilization by this volatile (Keppler and Wyllie 1990). Phillips and Evans (2004) examined $\mathrm{CO}_{2}$-rich and $\mathrm{CO}_{2}$-poor auriferous fluids, and argued that $\mathrm{CO}_{2}$ played a key role in gold mineralization, through buffering the $\mathrm{pH}$ range, and increasing gold concentration of the auriferous fluid. For the gold mineralization in the Hamadi gold deposit, the P-T conditions are estimated to be $270 \sim 390^{\circ} \mathrm{C}$ and $100 \sim 400 \mathrm{MPa}$. According to Benning 
and Seward (1986), $\left[\mathrm{Au}(\mathrm{HS})_{2}\right]^{-}$is the dominant gold-hydrosulphide complex in the ore-forming solutions within the range of temperatures between 200 and $400^{\circ} \mathrm{C}$, pressures around $200 \mathrm{MPa}$, as well as near-neutral $\mathrm{pH}$, so the gold in the ore-forming fluids in the Hamadi gold deposit might exist as $\left[\mathrm{Au}(\mathrm{HS})_{2}\right]^{-}$. Furthermore, $\mathrm{CO}_{2}$, as a weak acid, might help gold transport by buffering the fluid in a $\mathrm{pH}$ range where high gold concentration could be maintained by reduced sulphur complexes. Moreover, study of Lai and Chi (2007) suggests that $\mathrm{CO}_{2}$-rich vapour is capable of transporting large amounts of $\mathrm{Cu}$, and possibly $\mathrm{Au}$. The unmixing of fluids is also an important factor in gold deposition (Bower 1991). $\mathrm{CH}_{4}$ plays a more important role in unmixing than $\mathrm{CO}_{2}$ at $300^{\circ} \mathrm{C}$. The fluid will not be unmixed until the concentration of $\mathrm{CO}_{2}$ is above $15 \mathrm{~mol} \%$, but when $\mathrm{CH}_{4}$ is more than $5 \mathrm{~mol} \%$, unmixing may occurs (Van den Kerkhof and Thiery 2001). As shown above, $\mathrm{X}_{\mathrm{CH} 4}$ of carbonic fluid inclusions ranges from 0.4 to $14 \mathrm{~mol} \%$, with most of $\mathrm{X}_{\mathrm{CH} 4}$ around $5 \mathrm{~mol} \%$ in the gold-rich quartz veins of the Hamadi gold deposit, which indicate that unmixing occurred and played an important role in gold precipitation. Therefore, high $\mathrm{CO}_{2}$ content of fluid inclusions in gold mineralization at the Hamadi gold deposit, which is an important category of ore forming fluids, and $\mathrm{CO}_{2}-\mathrm{H}_{2} \mathrm{O}$ unmixing promotes the precipitation of $\mathrm{Au}$ in the Hamadi gold deposit. The Hamadi gold deposit displays features in accordance with orogenic type deposits (Groves et al. 2003; Table 5). The geological characteristics of the Hamadi gold deposit are also similar with other lode gold deposits in the Pan-African metallogenic belt from northeast Africa desert.

\section{Conclusions}


(1) Carbonic fluid inclusions are dominant both in gold-bearing veins and tiny veinlets in altered rocks at the Hamadi gold deposit. The melting temperatures of solid $\mathrm{CO}_{2}(\mathrm{~T} m, \mathrm{CO} 2)$ in both carbonic and $\mathrm{CO}_{2}-\mathrm{H}_{2} \mathrm{O}$ inclusions have a relatively narrow range $\left(-59.6^{\circ} \mathrm{C} \sim-56.6^{\circ} \mathrm{C}\right)$, and the homogenization temperatures of carbonic phases $(\mathrm{T} h, \mathrm{CO} 2)$ vary widely from -26.9 to $+23.7^{\circ} \mathrm{C}$, with most of the values clustering between +4.0 and $+20^{\circ} \mathrm{C}$, corresponding to densities from 0.73 to $1.03 \mathrm{~g} / \mathrm{cm}^{3}$.

(2) The carbonic inclusions in the Hamadi gold deposit are interpreted to have resulted from unmixing of an aqueous-carbonic mixture during retrogress metamorphism because of decreasing of P-T conditions; most of the water in the $\mathrm{CO}_{2}-\mathrm{H}_{2} \mathrm{O}$ fluids in the Hamadi deposit entered altered minerals such as sericite and biotite during intensive hydrothermal alteration and then $\mathrm{CO}_{2}$ was enriched relative to $\mathrm{H}_{2} \mathrm{O}$, which lead to the decrease of $\mathrm{SiO}_{2}$ solubility. Eventually, quartz veins are formed in fractures, and $\mathrm{CO}_{2}$ was trapped as carbonic inclusion in vein quartz.

(3) The $\mathrm{CO}_{2}$-rich fluid inclusions in the Hamadi gold deposit have been trapped with the minimum temperatures ranging from 270 to $390^{\circ} \mathrm{C}$. The estimated minimum trapping pressures range from 100 to $400 \mathrm{MPa}$, which are in agreement with the P-T conditions of regional metamorphism suggested by previous researchers. The gold in the ore-forming fluids in the Hamadi gold deposit might exist as [Au(HS) $\left.)_{2}\right]^{-} \mathrm{CO}_{2}$ had contributed to gold mineralization by buffering $\mathrm{pH}$ range and increasing the gold concentration in the fluids.

(4)The Hamadi gold deposit is characterized by medium-high homogenization temperatures, medium-low salinities, high density, and rich in $\mathrm{CO}_{2}-\mathrm{CH}_{4}$, controlled by 
shearing structures, which has similar metamorphic, structural, and mineralogical features that are characteristic of orogenic type deposits.

\section{Acknowledgements}

This work was funded by the project of China Geological Survey (1212011220911) and the National Natural Science Foundation of China (41672070; 41372096). We greatly appreciate colleagues from Tianjin North China Geological Exploration Bureau and Wuhan Center of China Geological Survey for helping field work and collecting samples. We thank journal reviewer Prof. Chi GX of the University of Regina and another anonymous reviewer, for their constructive comments which led to significant improvements in the manuscript. Our thanks extend to Dr. Ali Polat (Editor-in-Chief) and Dr. Tryhuba Brenda (Assistant to the Editor) for editorial handling. We also thank Prof. Fan HR of IGG-CAS for Raman measurement.

\section{References}

Almond, D.C., and Shaddad, M.Z. 1984. Setting of gold mineralization in the northern Red Sea Hills of Sudan. Economic Geology, 79:389-392.

Bohlke, J.K. 1982. Orogenic metamorphic-hosted gold-quartz veins. U.S. Geological Survey Open-File Report 795, pp. 70-76.

Burke, E.A. 2001. Raman microspectrometry of fluid inclusions. Lithos, 55:139-158.

Bakker, R.J., and Jansen, B.H. 1991. Experimental post-entrapment water loss from synthetic $\mathrm{CO}_{2}-\mathrm{H}_{2} \mathrm{O}$ inclusions in natural quartz. Geochimica et Cosmochimica Acta, 55:2215-2230.

Baker, T. 2002. Emplacement depth and carbon dioxide-rich fluid inclusions in 
intrusion-related gold deposits. Economic Geology, 97:1111-1117.

Beane, R.E. 1983. The Magmatic-Meteoric Transition. Geothermal Resources Council Special Report 13, pp. 245-253.

Benning, L.G., and Seward, T.M. 1986. Hydrosulphide complexing of $\mathrm{Au}(\mathrm{I})$ in hydrothermal solutions from 150-400 degrees C and 500-1500 bar. Geochimica et Cosmochimica Acta, 60:1849-1871.

Bailo, T., Schandelmeier, H., Franz, G., Sunb, C.H., and Stern, R.J. 2003. Plutonic and metamorphic rocks from the Keraf Suture (NE Sudan): A glimpse of Neoproterozoic tectonic evolution on the NE margin of W. Gondwana. Precambrian Research, 123:67-80.

Bodnar, R.J. 2003. Reequilibrium of fluid inclusions. Fluid Inclusions: analysis and interpretation. Mineralogical Association of Canada Short Course Series, $32: 213-231$.

Bower, T.S. 1991. The deposition of gold and other metals: pressures-induced fluid immiscibility and associated stable isotope signatures. Geochimica et Cosmochinica Acta, 55:247-2434.

Collins, P.L.F., 1979. Gas hydrates in $\mathrm{CO}_{2}$-bearing fluid inclusions and use freezing data for estimation of salinity. Economic Geology, 74:1435-1444.

Chi, G., Liu, Y., and Dubé, B. 2009. Relationship between $\mathrm{CO}_{2}$-dominated fluids, hydrothermal alterations and gold mineralization in the Red Lake greenstone belt, Canada. Applied Geochemistry, 24:504-516.

Chi, G.X., Dubé, B., Williamson, K., and Williams-Jones, A.E. 2006. Formation of the 
Campbell-Red Lake gold deposit by $\mathrm{H}_{2} \mathrm{O}$-poor, $\mathrm{CO}_{2}$-dominated fluids. Mineralium Deposita, 40:726-741.

Chen, H.Y., Chen, Y.J., and Baker, M.J. 2012. Isotopic geochemistry of the Sawayaerdun orogenic-type gold deposit, Tianshan, northwest China: implications for ore genesis and mineral exploration. Chemical Geology, 310-311:1-11.

Deschamps, Y., and Lescuyer, J.L. 2002. Selection de zones a potential aurifere dans les Red Sea Hills, NE Sudan. BRGM/RC-51810-FR pp.1-45.

El-Gaby, S., List, F.K., and Tehrani, R. 1988. Geology, evolution and metallogenesis of the Pan-African Belt in Egypt. In: El-Gaby S, Greiling R.O. (Eds.), The Pan-African Belt of northeast Africa and adjacent areas. Friedrich Vieweg und Sohn, Braunschweig/Wiesbaden, 17-68p.

Evandro, L.K., and Kazuo, F. 2010. Origin of the $\mathrm{CO}_{2}$-only fluid inclusions in the Palaeoproterozoic Carará vein-quartz gold deposit, Ipitinga Auriferous District, SE-Guiana Shield, Brazil: Implications for orogenic gold mineralization. Ore Geology Reviews, 37:31-40.

Fan, H.R., Zhai, M.G., Xie, Y.H., and Yang, J.H. 2003. Ore-forming fluids associated with granite-hosted gold mineralization at the Sanshandao deposit, Jiaodong gold province, China. Mineralium Deposita, 38:739-750.

Fu, B., Mernagh, T.P., Fairmaid, A.M., Phillips, D., and Kendrick, M.A. 2014. $\mathrm{CH}_{4}-\mathrm{N}_{2}$ in the Maldon gold deposit, central Victoria, Australia. Ore Geology Reviews, 58:225-237.

Goldfarb, R.J., Newberry, R.J., Pickthorn, W.J., and Gent, C.A. 1991. Oxygen, 
hydrogen, and sulfur isotope studies in the Juneau gold deposit, southeastern Alaska: constraints on the origin of hydrothermal fluids. Economic Geology, 86, $66-80$.

Groves, D.I., Goldfarb, R.J., Gebre-Mariam, M., Hagemann, S.G., and Robert, F. 1998. Orogenic gold deposits: A proposed classification in the context of their crustal distribution and relationship to other gold deposit types. Ore Geology Reviews, $13: 7-27$.

Goldfarb, R.J., Groves, D.I., and Gardoll, S. 2001. Orogenic gold and geologic time: A global synthesis. Ore Geology Reviews, 18:1-75.

Groves, D.I., Goldfarb, R.J., Robert, F., and Hart, C.J.R. 2003. Gold deposits in metamorphic belts: overview of current understanding, outstanding problems, future research, and exploration significance. Economic Geology, 98:1-29.

Goldfarb, R.J., Baker, T., Dube, B., Groves, D.I., Hart, C.J.R., and Gosselin, P. 2005. Distribution, Character, and Genesis of Gold Deposits in Metamorphic Terranes. Economic Geology 100th Anniversary Volume, 407-450p.

Goldfarb, R.J., Ayuso, R., Miller, M.L., Ebert, S.W., Marsh, E.E., Petsel, S.A., Miller, L.D., Bradley, D.C., Johnson, C., and McClelland, W. 2004. The late cretaceous Donlin creek gold deposit, southwestern Alaska: controls on epizonal ore formation. Economic Geology, 99:643-671.

Graupner, T., Kempe, U., Spooner, E.T.C., Bray, C.J., Kremenetsky, A.A., and Irmer, G. 2001. Microthermometric, laser Raman spectroscopic, and volatile-ion chromatographic analysis of hydrothermal fluids in the Paleozoic Muruntau 
Au-bearing quartz vein ore field, Uzbekistan. Economic Geology, 96:1-23.

Goldstein, R.H., and Reynolds, T.J. 1994. Systematics of fluid inclusions in diagenetic minerals. SEPM Short Cour 31, 1-199p.

Garba, I.A., and kande, S.O. 1992. The origin and significance of nonaqueous $\mathrm{CO}_{2}$ fluid inclusions in the auriferous veins of Bin Yauri, northwestern Nigeria. Mineralium Deposita, 27:249-255.

Gu, L. X., Zheng, Y.C., and Tang, X.Q. 2007. Copper, gold and silver enrichment in ore mylonites within massive sulphide orebodies at Hongtoushan VHMS deposit, N. E. China. Ore Geology Reviews, 30:1-29.

Ho, S.E. 1987. Fluid inclusions: their potential as an exploration tool for Archaean gold deposits. In:Ho, S.E., Groves, D.I. (Eds.), RecentAdvances inUnderstanding Precambrian Gold Deposits. Geology Department and University Extension, University of Western Australia, 239-264p.

Hollister, L.S. 1990. Enrichment of $\mathrm{CO}_{2}$ in fluid inclusions in quartz by removal of $\mathrm{H}_{2} \mathrm{O}$ during crystal-plastic deformation. Journal of Structural Geology, 12:895-901.

Hilmy, M.E., and Osman, A. 1989. Remobilization of gold from a chalcopyrite-pyrite mineralization Hamash gold mine, Southeastern Desert, Egypt. Mineralium Deposita, 24:244-249.

Hussein, A.A.A. 1990. Mineral deposits. In: Said, R. (Ed.), The Geology of Egypt. A.A Balkema, Rotterdam/Brookfield, 511-566p.

Harraz, H.Z., and El-Dahhar, M.A. 1993. Nature and composition of gold-forming 
fluids at Umm Rus area, Eastern Desert, Egypt: evidence from fluid inclusions in vein materials. Journal of African Earth Sciences, 16:341-353.

Harraz, H.Z. 2002. Fluid inclusions in the mesothermal gold deposit at Atud mine, Eastern Desert, Egypt. Journal of African Earth Sciences, 35:347-363.

Holness, M.B. 1993. Temperature and pressure dependance of quartz-aqueous fluid dihedral angles: the control of adsorbed $\mathrm{H}_{2} \mathrm{O}$ on the permeability of quartzites. Earth and Planetary Science Letters, 117:363-377.

Higgins, N.C. 1980. Fluid inclusion evidence for the transport of carbonate complexes in hydrothermal solutions. Canadian Journal of Earth Sciences, 17:823-830.

Hrstka, T., Dubessy, J., and Zachariáš, J. 2011. Bicarbonate-rich fluid inclusions and hydrogen diffusion in quartz from the Libčice orogenic gold deposit, Bohemian Massif. Chemical Geology, 281:317-332.

Johnson, E.L., and Hollister, L.S. 1995. Syndeformational fluid trapping in quartz: determining the pressure-temperature conditions of deformation from fluid inclusions and the formation of pure $\mathrm{CO}_{2}$ fluid inclusions during grain-boundary migration. Journal of Metamorphic Geology, 13:239-249.

Jia, Y., Li, X., and Kerrich, R. 2001. Stable isotope (O, H, S, C and N) systematics of quartz vein systems in the tubidite-hosted Central and North Deborah gold deposits of the Bendigo gold field, Central Victoria, Australia: constraints on the origin of oreforming fluids. Economic Geology, 96:705-721.

Kolb, J., Kisters, A.F.M., Hoernes, S., and Meyer, F.M. 2000. The origin of fluids and nature of fluid-rock interaction in mid-crustal auriferous mylonites of the Renco 
mine, southern Zimbabwe. Mineralium Deposita, 35:109-125.

Klein, E.L., Harris, C., Renac, C., Giret, A., Moura, C.A.V., and Fuzikawa, K. 2006. Fluid inclusion and stable isotope $(\mathrm{O}, \mathrm{H}, \mathrm{C}$, and $\mathrm{S})$ constraints on the genesis of the Serrinha gold deposit, Gurupi Belt, Northern Brazil. Mineralium Deposita, 41:160-178.

Klein, E.L., and Fuzikawa, K. 2010. Origin of the $\mathrm{CO}_{2}$-only fluid inclusions in the Palaeoproterozoic Carará vein-quartz gold deposit, Ipitinga Auriferous District, SE-Guiana Shield, Brazil: Implications for orogenic gold mineralisation. Ore Geology Reviews, 37:31-40.

Klemd, R., and Hirdes, W. 1997. Origin of an unusual fluid composition in Early Proterozoic Palaeoplacer and lode-gold deposits in Birimian greenstone terranes of West Africa. South African Journal of Geology, 100:405-414.

Klemd, R. 1998. Comment on the paper by Schmidt Mumm et al. High $\mathrm{CO}_{2}$ content of fluid inclusions in gold mineralisations in the Ashanti Belt, Ghana: A new category of ore forming fluids? Mineral Deposita, 33:317-319.

Kerrick, D.M., and Caldera, K. 1998. Metamorphic $\mathrm{CO}_{2}$ degassing from orogenic belts. Chemical Geology, 145:213-232.

Kerrich, R., Goldfarb, R.J., Groves, D.I., Garwin, S., and Jia, Y.F. 2000. The characteristics, origins and geodynamic settings of supergiant gold metallogenic provinces. Science in China Series D, 43:1-68.

Keppler, H., and Wyllie, P.J. 1990. Role of fluids in transport and fractionation of uranium and thorium in magmatic processes. Nature, 348:531-533. 
Lai, J., and Chi, G. 2007. $\mathrm{CO}_{2}$-rich fluid inclusions with chalcopyrite daughter mineral from the Fenghuangshan $\mathrm{Cu}-\mathrm{Fe}-\mathrm{Au}$ deposit, China: implications for metal transport in vapour. Mineralium Deposita, 42:293-299.

Liu, G., Wang, X.B., and Wen, Q.B. 1997. Chemical composition of gas from mantle xenoliths in alkli-basalt from Damaping, Hebei, Chinese Science Bulletin, 42:470$-472$.

Li, H., and Hu, J.Y. 2012. Geochemical characteristics and genesis of Hamadi gold deposit in Sudan. Contributions to Geology and Mineral Resources Research, 2: 222-226. (in Chinese with English abstract).

Mumm, A.S., Oberthür, T., Vetter, U., and Blenkinsop, T.G. 1997. High $\mathrm{CO}_{2}$ content of fluid inclusions in gold mineralisations in the Ashanti Belt, Ghana: A new category of ore forming fluids? Mineralium Deposita, 32:107-118.

Marshall, B., and Gilligan, L.B. 1987. An introduction to remobilisation: information from ore-body geometry and experimental considerations. Ore Geology Reviews, $2: 87-131$

OberthuÈr, T., Schmidt Mumm, A., Vetter, U., Simon, K., and Amanor, J. 1996. Gold mineralization in the Ashanti belt of Ghana: Genetic constraints of the stable isotope geochemistry. Economic Geology, 91:289-301.

Pohl, W. 1988. Precambrian metallogeny of Northeast-Africa, the Pan-African Belt of northeast Africa and adjacent areas. Friedrich Vieweg und Sohn, Braunschweig/Wiesbaden, 319-341p.

Phillips, G.N., and Powell, R. 1993. Link between gold provinces. Economic Geology, 
$88: 1084-1098$.

Phillips, G.N., and Evans, K.A. 2004. Role of $\mathrm{CO}_{2}$ in the formation of gold deposits, Nature, 429:860-863.

Reinhardt, M.C., and Davison, I. 1990. Structural and lithoiogical controls on gold deposition in the shear zone-hosted Fazenda Brasileiro Mine, Bahia state, Northeast Brazil. Economic Geology, 85:952-967.

Roedder, E., and Bodnar, R.J. 1980. Geologic pressure determinations from fluid inclusion studies. Annual Review of Earth and Planetary Sciences, 8:263-301.

Romberger, S.B. 1990. Transport and deposition of gold in hydrothermal systems. In: Robert, F., Shearan, P.A., Green, S.B. (Eds.), Greenstone Gold and Crustal Evolution. : NUNA Conference Volume. Geological Association of Canada, 61-66p.

Ridley, J.R., and Diamond, L.W. 2000. Fluid chemistry of lode-gold deposits, and implications for genetic models. In: Hagemann, S.G., Brown, P. (Eds.), Gold in 2000. Reviews in Economic Geology. Society of Economic Geologists, Inc, 141-162p.

Schwartz, M.O., Oberthür, T., Amanor, J., and Gyapong, W.A. 1992. Fluid inclusion reequililibration and P-T-X constraints on fluid evolution in the Ashanti gold deposit, Ghana. European Journal of Mineralogy, 4:1017-1033.

Schmidt Mumm, A., OberthuÈr, T., Vetter, U., and Blenkinsop, T.G. 1997. High $\mathrm{CO}_{2}$-content of fluid inclusions in gold mineralisations in the Ashanti Belt, Ghana: a new category of ore forming fluids? Mineral Deposita, 32:107-118. 
Schmidt Mumm, A., Oberthür, T., Vetter, U., and Blenkinsop, T.G. 1998. High $\mathrm{CO}_{2}$ content of fluid inclusions in gold mineralisations in the Ashanti Belt, Ghana: A new category of ore forming fluids? - a reply. Mineralium Deposita, 33:320-322.

Stern, R.J. 1994. Neoproterozoic (900-550 Ma) Arc Assembly and continental collision in the East African Orogen. Annual Review of Earth and Planetary Sciences, 22: 319-351.

Schandelmeier, H., Wipfler, E., Kuster, D., Sultan, M., Becker, R., Stern, R.J., and Abdelsalam, M.G. 1994. Atmur-Delgo suture: a Neoproterozoic oceanic basin extending into the interior of northeast Africa. Geology, 22:563-566.

Santosh, M., Jackson, D.H., Harris, N.B.W., and Mattey, D.P. 1991. Carbonic fluid inclusions in South Indian granulites: evidence for entrapment during charnockite formation. Contributions to Mineralogy and Petrology, 108:318-330.

Swanenberg, H.E.C. 1979. Phase equilibria in carbonic systems and their application to freezing studies of fluid inclusions. Contributions to Mineralogy and Petrology, 68:303-306.

Shepherd, T.J., Rankin, A.H., and Alderton, D.H.M. 1985. A Practical Guide to Fluid Inclusion Studies. Blackie: Chapman and Hall, 1-239p.

Taylor, H.P. 1997. Oxygen and hydrogen isotope relationships in hydrothermal mineral deposits. In: Barnes, H.L. (Ed.), Geochemistry of Hydrothermal Ore Deposits. Wiley and Sons New York, 229-302p.

Trench, A., and Groves, D. 2015. The Western Arabian-Nubian Shield: A Rapidly Emerging Gold Province. SEG News Letter, 1-16p. 
Takla, M.A., El-Dougdoug, A.A., Rasmy, A.H., Gad, M.A., and El-Tabbal, H.K. 1990. Origin of Umm El-Eiga gold mineralization, south Eastern Desert, Egypt. Egyptian Mineralogists, 2:3-20.

Thiéry, R., Vidal, J., and Dubessy, J. 1994. Phase equilibria modelling applied to fluid inclusions: Liquid-vapour equilibria and calculation of the molar volume in the $\mathrm{CO}_{2}-\mathrm{CH}_{4}-\mathrm{N}_{2}$ system. Geochimimica et Cosmochimica Acta, 58:1073-1082.

Van den Kerkhof, A., and Thiéry, R. 2001. Carbonic inclusions. Lithos, 55: 49-68.

Wilde, A.R., Layer, P., Mernagh, T., and Foster, J. 2001. The giant Muruntau gold deposit: Geologic, geochronologic, and fluid inclusion constraints on ore genesis. Economic Geology, 96:633-644.

Wilkinson, J.J. 2001. Fluid inclusions in hydrothermal ore deposits. Lithos, $55: 229-272$.

Wilmart, E., Clocchiatti, R., Duchesne, J.C., and Touret, J.L.R. 1991. Fluid inclusions in charnockites from the Bjerkreim-Sokndal massif (Rogaland, southwestern Norway): fluid origin and in situ evolution. Contributions to Mineralogy and Petrology, 108:453-462.

Wille, S.E., and Klemd, R. 2004. Fluid inclusion studies of the Abawso gold prospect, near the Ashanti Belt, Ghana. Mineralium Deposita, 39:31-45.

Walther, J.V., and Orville, P.M. 1983. The extraction-quench technique for determination of the thermodynamic properties of solute complexes: application to quartz solubility in fluid mixtures. American Mineralogist, 68:731-741.

Xu, J.H., Ding, R.F., Xie, Y.L., Zhong, C.H., and Yuan, X. 2005. Pure $\mathrm{CO}_{2}$ fluids in 
the Sarekoubu gold deposit at southern margin of Altai Mountains in Xinjiang, West China. Chinese Science Bulletin, 50:333-340.

Xu, J.H., Shan, L.H., Ding, R.F., Hart, C.J., Wang, L.L., and Wei, X.F. 2008. Carbonic fluid inclusion assemblages and their geological significance at the Tiemurte lead-zinc deposit, Altay. Acta Petrologica Sinica, 24:2094-2103. (in Chinese with English abstract).

Xu, J.H., Wang, J.X., Xiang, P., Li, Y.H., Xiao, X., Zhang, H., and Cheng, X.H. 2014. Extremely $\mathrm{CO}_{2}$-rich fluid inclusions in an orogenic gold deposit: Hamadi gold deposit of Sudan. Acta Petrologica Sinica, 30:1040-1048. (in Chinese with English abstract).

Xavier, R.P., and Foster, R.P. 1999. Fluid evolution and chemical controls in the Fazenda Maria Preta (FMP) gold deposit, Rio Itapicuru Greenstone Belt, Bahia, Brazil. Chemical Geology, 154:133-154. 


\section{Figure Captions}

Fig. 1 Regional map of the Hamadi gold deposit, Sudan (Modified from Bailo et al. 2003)

Fig. 2 Mine map of the Hamadi gold deposit, Sudan (Modified from Bailo et al. 2003) Fig. 3 Photographs of wallrock alteration at the Hamadi gold deposit

(A) Disseminated pyrite occurring as thin filament in pyritizatic and carbonificatic biotite-quartz schist. HMD112-1; (B) Sparse pyrite in carbonificatic hornblende-quartz schist. HMD109-1; (C) A rotated pyrite metacryst in beresitizatic mylonitic schist, HMD111-1; (D) Stretched pyrite metacrysts in beresitizatic schist, HMD114-1, reflected-light.

Fig. 4 Photomicrographs showing assemblages of ore mineral in the Hamadi gold deposit

(A) Chalcopyrite (Ccp) replacing pyrite in a tiny vein within altered amphibole-quartz schist, HMD109-4, reflected-light; (B) Disseminated pyrite occurring in pyritizatic and carbonificatic biotite-quartz schist, pyritization schist, HMD111-1, (+); (C) A rotated pyrite metacryst in beresitizatic mylonitic schist, HMD114-3; (D) Stretched pyrite metacrysts in beresitizatic schist, HMD111-3; (E) Gold gains (Au) occurring in fissures within quartz of Au-bearing pyritization schist, HMD111-b1, reflected-light; (F) Gold gains (Au) occurring as inclusions in a coarse pyrite (Py) grain of pyritization schist, HMD111-b1, reflected-light; (G) Sparse pyrite in carbonificatic hornblende-quartz schist, HMD109-1, reflected-light; (H) Disseminated pyrite occurring in pyritizatic and carbonificatic biotite-quartz schist, pyritization schist, HMD111-1, (+); (I) Coarse-grain is replaced, pyritization schist, HMD112-1, reflected-light.

Fig. 5 Fluid inclusions in gold-bearing veins of the Hamadi gold deposit, Sudan (A) Carbonic fluid inclusions within a quartz grain, $\mathrm{HMD} 201$; (B) Isolated $\mathrm{CO}_{2}-\mathrm{H}_{2} \mathrm{O}$ inclusions in gray 
vein quartz, HMD201; (C) $\mathrm{CO}_{2}-\mathrm{H}_{2} \mathrm{O}$ inclusions in gray vein quartz, HMD203; (D) Carbonic fluid inclusions distributed randomly within a quartz grain, HMD201; (E) Isolated carbonic inclusions occurring in a quartz grain, associated with $\mathrm{CO}_{2}-\mathrm{H}_{2} \mathrm{O}$ inclusions, HMD204; (F) Two FIAs composed of carbonic inclusions in vein quartz, HMD203; (G) Several carbonic FIAs occurring within healed fissures in vein quartz, HMD205; $(\mathrm{H})$ Isolated $\mathrm{CO}_{2}-\mathrm{H}_{2} \mathrm{O}$ inclusions associated with carbonic fluid inclusions in gray vein quartz, HMD203; (I) A group of $\mathrm{CO}_{2}-\mathrm{H}_{2}$ Oinclusions distributed randomly, associated with a few isolated carbonic inclusions in gray vein quartz, HMD201

Fig. 6 Carbonic fluid inclusions in pyrite quartz veins at the Hamadi gold deposit, North Sudan.

(A) Carbonic fluid inclusions associated with a few $\mathrm{CO}_{2}-\mathrm{H}_{2} \mathrm{O}$ inclusions, not cutting a quartz grain, HMD113; (B) carbonic fluid inclusions associated with a few $\mathrm{CO}_{2}-\mathrm{H}_{2} \mathrm{O}$ inclusions, not cutting a quartz grain, distributed in short healed fractures, HMD115; (C) one group of carbonic fluid inclusions(NE-SW, late) and one group of carbonic fluid inclusions(NW-SE, early) in quartz vein, HMD205-b; (D) carbonic fluid inclusions, not cutting a quartz grain, HMD112. Note:The direction 'NW-SE' described in the pictures is not a real orientation. The upper points to north so as to read easily,

Fig. 7 Histograms showing solid $\mathrm{CO}_{2}$ melting temperatures $\left(\mathrm{T}_{m, \mathrm{CO}}\right), \mathrm{CO}_{2}$ homogenization temperatures $\left(\mathrm{T}_{h, \mathrm{CO} 2}\right)$ and final homogenization temperatures $\left(\mathrm{T}_{h, t o t}\right)$ for FIA and non-FIA carbonic ( $\mathrm{C}$ type) and $\mathrm{CO}_{2}-\mathrm{H}_{2} \mathrm{O}$ inclusions ( $\mathrm{CW}$ type) in the Hamadi deposit. Note: the temperature value used for FIAs is average of each FIA, not every inclusion, e.g., type carbonic fluid inclusions within a single FIA have a very narrow ranges of $\mathrm{T}_{m, \mathrm{CO} 2}$ and $\mathrm{T}_{h, \mathrm{CO} 2}$, such as from -56.7 to $-57.0 \square\left(\mathrm{T}_{m, \mathrm{CO} 2}\right)$ and from 3.2 to $4.0 \square$ ( $\mathrm{T}_{h, \mathrm{CO} 2}$ homogenized to liquid $\mathrm{CO}_{2}$ phase) in sample HMD201. 
Fig. 8 An example of thermometry data for a carbonic fluid inclusion assemblage (FIA)

(A) Carbonic inclusions occurring as clusters (FIA) in a quartz grain (Sample HMD202-d); (B) Histograms of the melting temperatures of solid $\mathrm{CO}_{2}\left(\mathrm{~T}_{, \mathrm{CO} 2}\right)$; (C) Homogenization temperatures ( $\left(h_{, \mathrm{CO} 2}\right.$, to liquid $\mathrm{CO}_{2}$ ) within the FIA

Fig. 9 Laser Raman Microspectra of carbonic fluid inclusions

(A) $\mathrm{CH}_{4^{-}}$and $\mathrm{CO}_{2}$-spectrum of single phase in carbonic fluid inclusion, $\mathrm{HMD} 201$; (B) $\mathrm{CH}_{4^{-}}$and $\mathrm{CO}_{2}$-spectrum of single phase in carbonic fluid inclusion,HMD202; (C) $\mathrm{N}_{2}-\mathrm{CH}_{4}$ - and $\mathrm{CO}_{2}$-spectrum of vapor-liquid two phase in fluid inclusion, $\mathrm{HMD} 204$; (D) $\mathrm{CH}_{4^{-}}$and $\mathrm{CO}_{2}$-spectrum of single phase in carbonic fluid inclusion, HMD205.

Fig. $10 \delta^{18} \mathrm{O}_{\mathrm{H} 2 \mathrm{O}-} \delta \mathrm{D}_{\mathrm{H} 2 \mathrm{O}}$ plots of the ore fluids at the Hamadi gold deposit. Domains for metamorphic and magmatic fluids are cited from Taylor (1997). The field for the Juneau gold belts revised after Goldfarb et al. (1991). The field for Majority of lode gold deposits revised after Goldfarb et al. (2004).

Fig. 11 Homogenization temperature versus salinity diagram for fluid inclusions in Hamadi gold deposit. Fields for various fluid types after Beane (1983).

Fig. 12 Homogenization temperatures versus salinities diagram. After Wilkinson (2001).

Fig. $13 \mathrm{~T} m, \mathrm{CO}_{2}-\mathrm{T} h, \mathrm{CO} 2$ of carbonic inclusions and carbonic phase in $\mathrm{H}_{2} \mathrm{O}-\mathrm{CO}_{2}$ inclusions(drawing after Thiéry et al. 1994 and van den Kerkhof and Thiéry 2001)

Fig. 14 Trapping $P-T$ conditions of carbonic fluid inclusions at the Hamadi gold 
deposit (phase diagram after Winter 2001)

\section{Table Captions}

Table 1 Microthermometric data of fluid inclusions occurring in FIAs from vein quartz in the Hamadi gold deposit

Table 2 Microthermometric data of fluid inclusions occurring in Non-FIAs from vein quartz in the Hamadi gold deposit

Table 3 Comprehensive thermometry of fluid inclusions in quartz veinlets from gold-bearing altered rocks of the the Hamadi gold deposit

Table 4 Comparisons of major characteristics of the Hamadi gold deposit and other deposit by $\mathrm{H}_{2} \mathrm{O}$-poor, $\mathrm{CO}_{2}$-dominated fluids

Table 5 Comparisons of major characteristics of the Hamadi gold deposit and orogenic deposits 


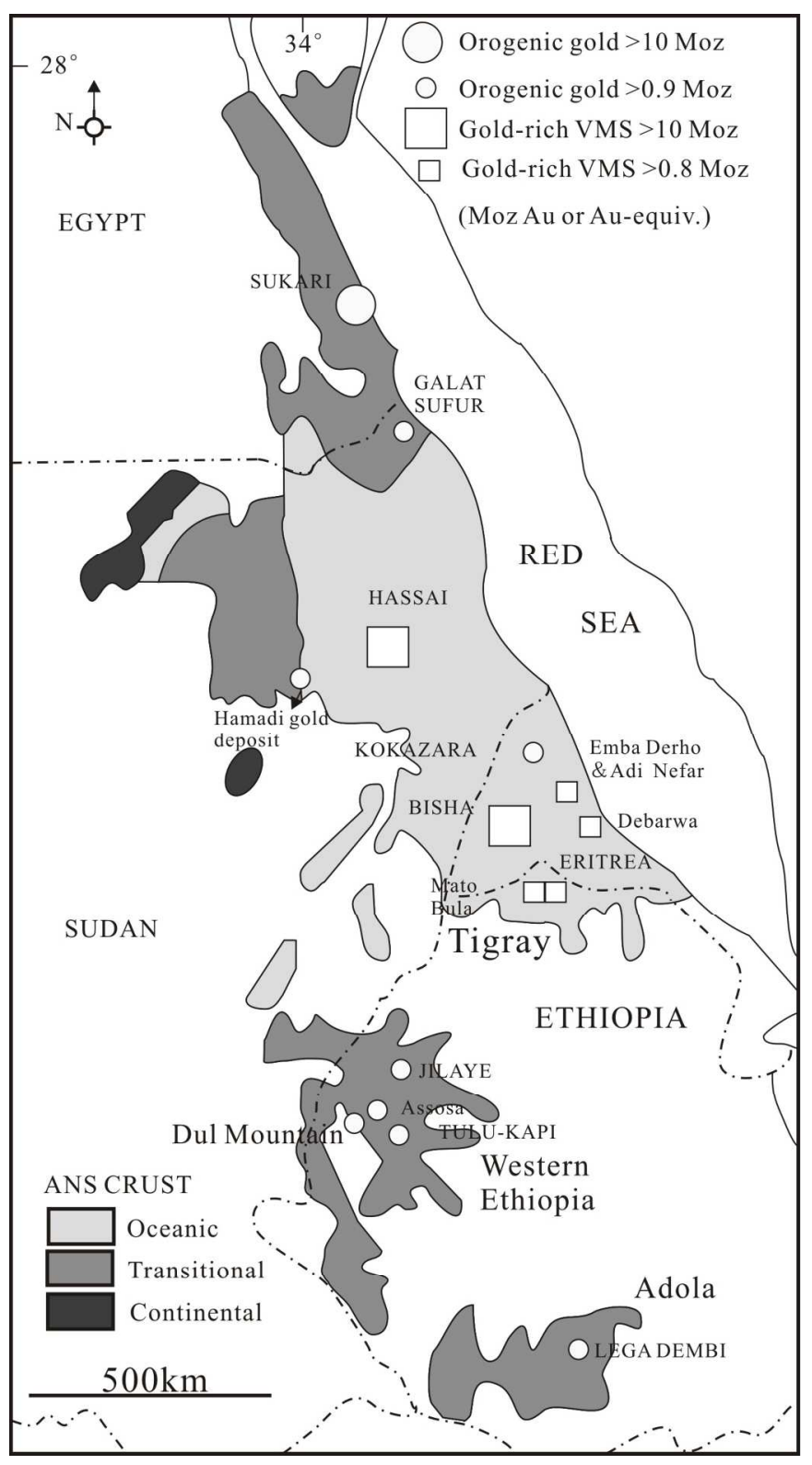

Fig.1 Regional map of the Hamadi gold deposit, Sudan (Modified from Bailo et al., 2003) $197 \times 360 \mathrm{~mm}(300 \times 300$ DPI $)$ 


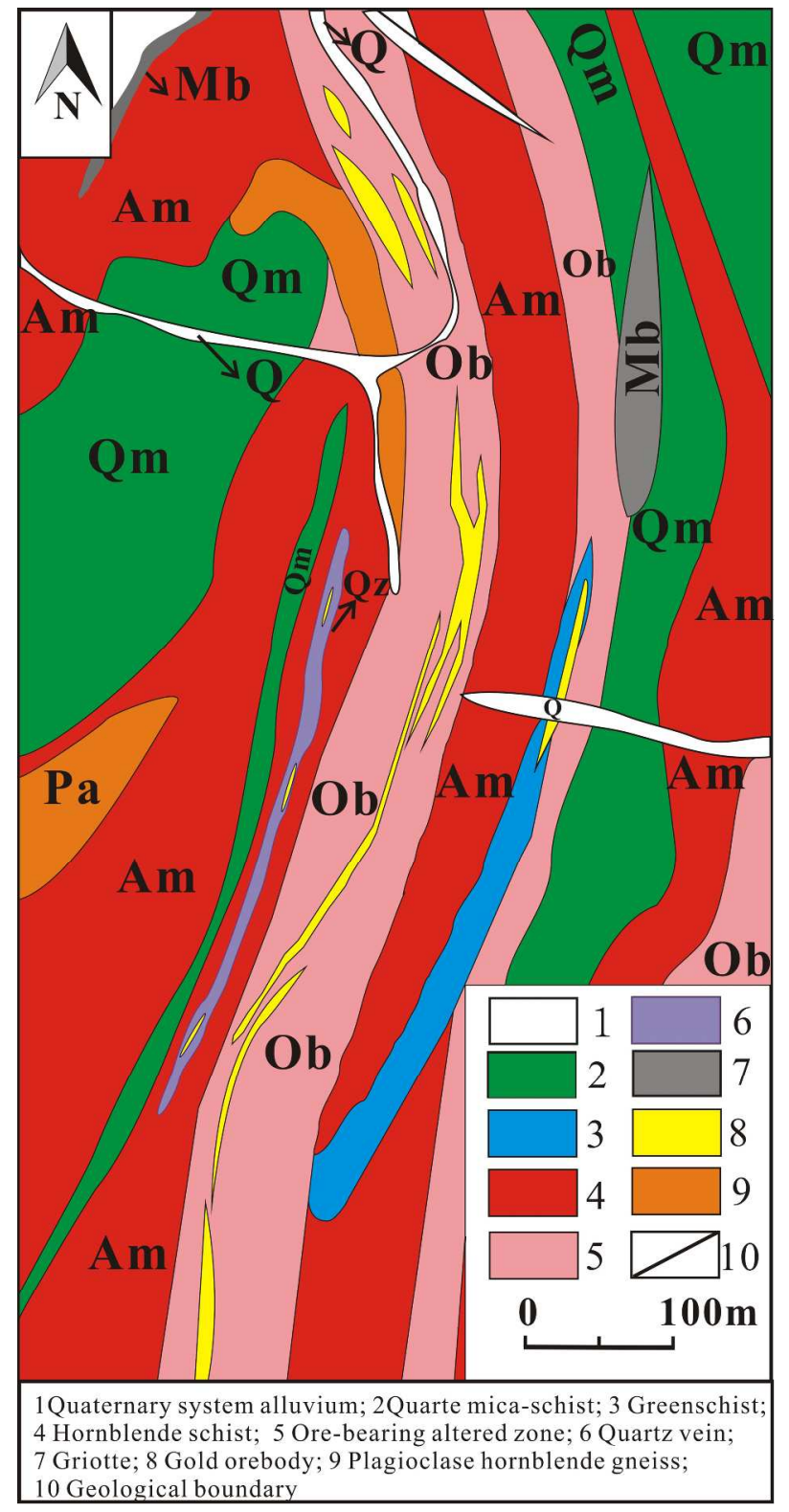

Fig.2 Mine map of the Hamadi gold deposit, Sudan (Modified from Bailo et al., 2003) $315 \times 624 \mathrm{~mm}(300 \times 300 \mathrm{DPI})$ 


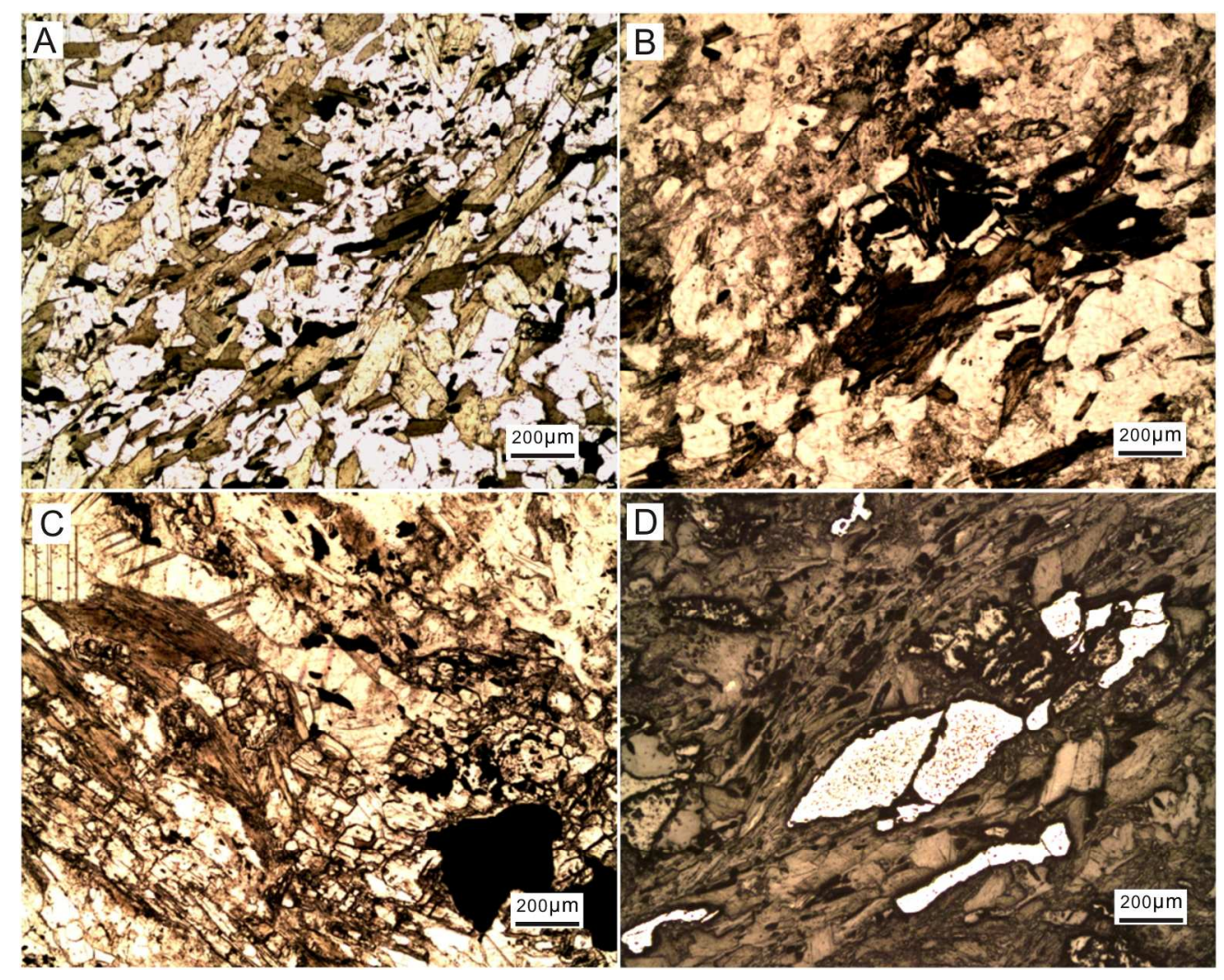

Fig. 3 Photographs of wallrock alteration at the Hamadi gold deposit

(A) Disseminated pyrite occurring as thin filament in pyritizatic and carbonificatic biotite-quartz schist. HMD112-1 ; (B) Sparse pyrite in carbonificatic hornblende-quartz schist. HMD109-1; (C) A rotated pyrite metacryst in beresitizatic mylonitic schist, HMD111-1; (D) Stretched pyrite metacrysts in beresitizatic schist, HMD114-1, reflected-light.

$230 \times 183 \mathrm{~mm}(300 \times 300 \mathrm{DPI})$ 


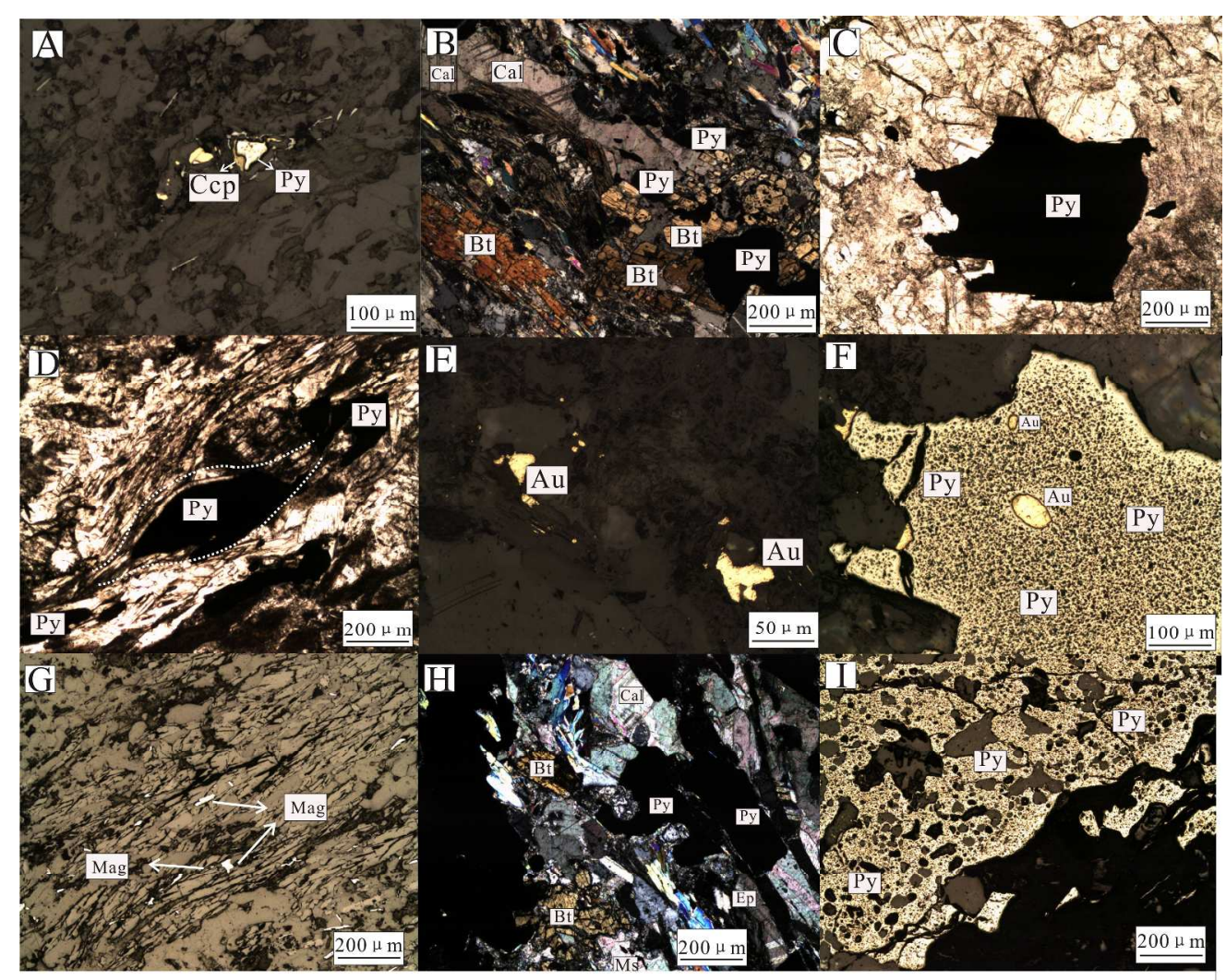

Fig. 4 Photomicrographs showing assemblages of ore mineral in the Hamadi gold deposit (A) Chalcopyrite (Ccp) replacing pyrite in a tiny vein within altered amphibole-quartz schist, HMD109-4, reflected-light; (B) Disseminated pyrite occurring in pyritizatic and carbonificatic biotite-quartz schist, pyritization schist, HMD111-1, (+); (C) A rotated pyrite metacryst in beresitizatic mylonitic schist, HMD1143; (D) Stretched pyrite metacrysts in beresitizatic schist, HMD111-3; (E) Gold gains (Au) occurring in fissures within quartz of Au-bearing pyritization schist, HMD111-b1, reflected-light; (F) Gold gains (Au) occurring as inclusions in a coarse pyrite (Py) grain of pyritization schist, HMD111-b1, reflected-light; (G) Sparse pyrite in carbonificatic hornblende-quartz schist, HMD109-1, reflected-light; (H) Disseminated pyrite occurring in pyritizatic and carbonificatic biotite-quartz schist, pyritization schist, HMD111-1, (+); (I) Coarse-grain is replaced, pyritization schist, HMD112-1, reflected-light. 

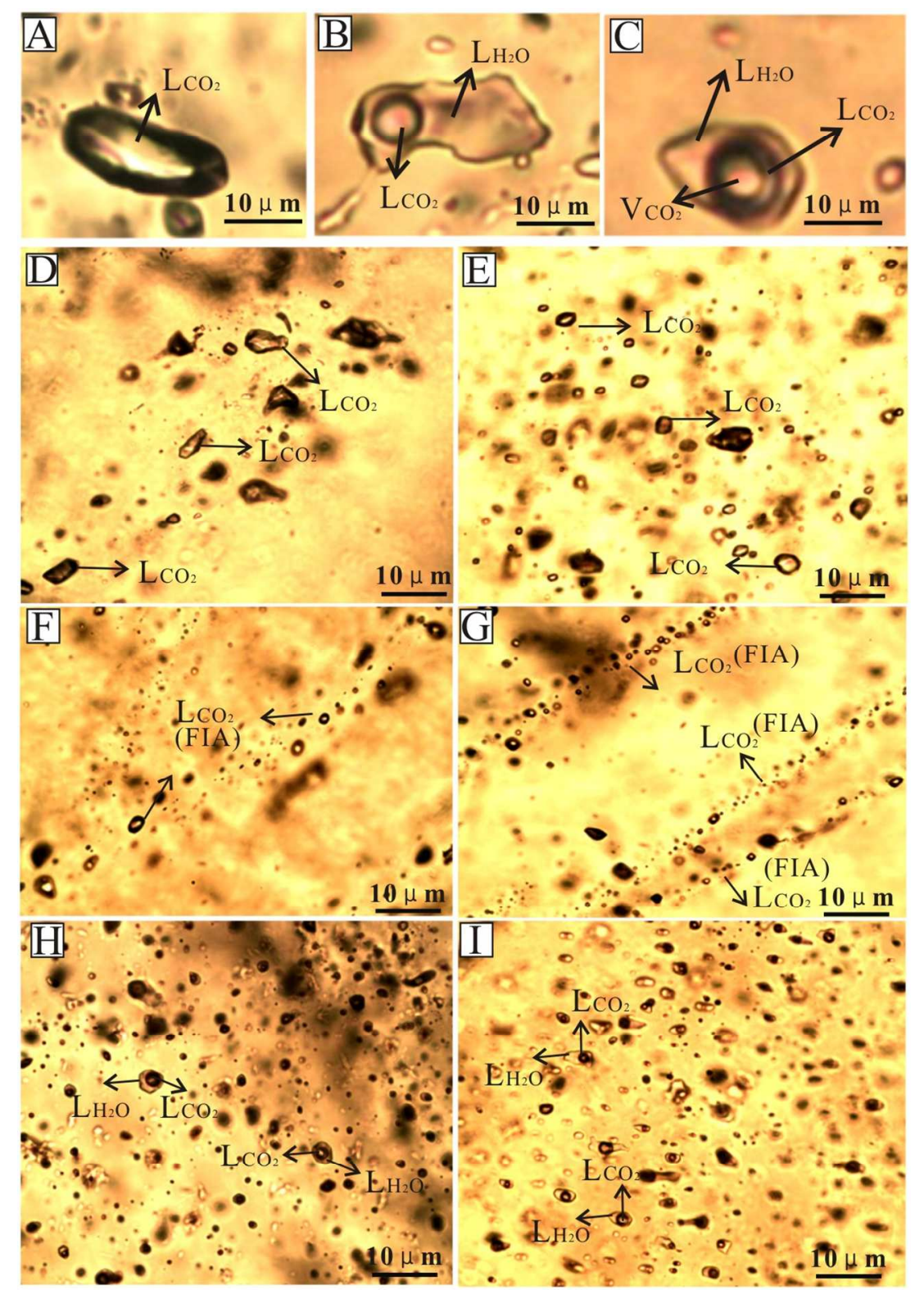

Fig. 5 Fluid inclusions in gold-bearing veins of the Hamadi gold deposit, Sudan

(A) Carbonic fluid inclusions within a quartz grain, HMD201; (B) Isolated $\mathrm{CO} 2-\mathrm{H} 2 \mathrm{O}$ inclusions in gray vein quartz, HMD201; (C) CO2-H2O inclusions in gray vein quartz, HMD203; (D) Carbonic fluid inclusions distributed randomly within a quartz grain, HMD201; (E) Isolated carbonic inclusions occurring in a quartz grain, associated with CO2-H2O inclusions, HMD204; (F) Two FIAs composed of carbonic inclusions in vein quartz, HMD203; (G) Several carbonic FIAs occurring within healed fissures in vein quartz, HMD205; (H) Isolated $\mathrm{CO} 2-\mathrm{H} 2 \mathrm{O}$ inclusions associated with carbonic fluid inclusions in gray vein quartz, HMD203; (I) A group of $\mathrm{CO} 2-\mathrm{H} 2 \mathrm{O}$ inclusions distributed randomly, associated with a few isolated carbonic inclusions in gray vein quartz, HMD201 


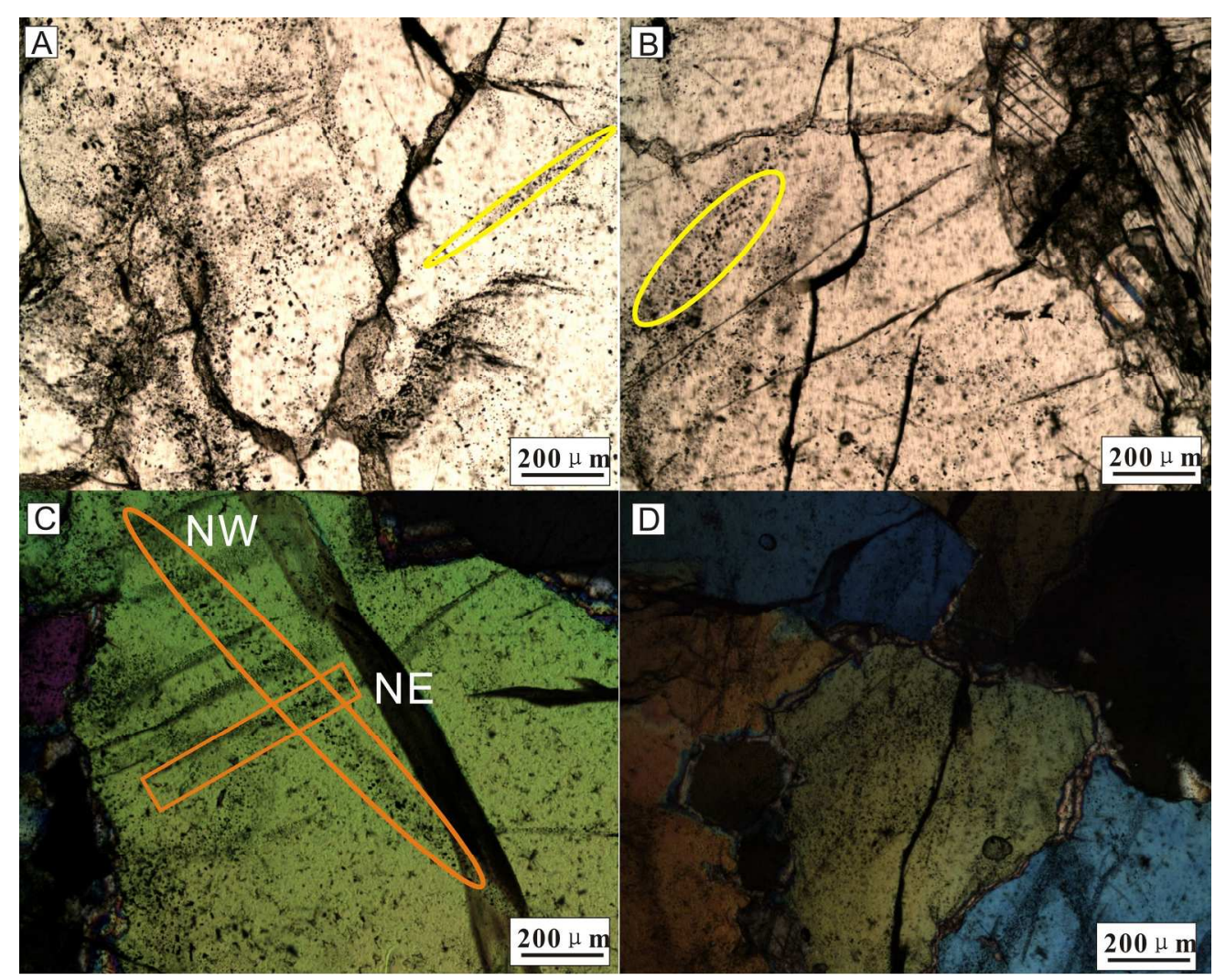

Fig. 6 Carbonic fluid inclusions in pyrite quartz veins at the Hamadi gold deposit, North Sudan. (A) Carbonic fluid inclusions associated with a few CO2-H2O inclusions, not cutting a quartz grain, HMD113; (B) carbonic fluid inclusions associated with a few $\mathrm{CO} 2-\mathrm{H} 2 \mathrm{O}$ inclusions, not cutting a quartz grain, distributed in short healed fractures, HMD115; (C) one group of carbonic fluid inclusions(NE-SW, late) and one group of carbonic fluid inclusions(NW-SE, early) in quartz vein, HMD205-b; (D) carbonic fluid inclusions, not cutting a quartz grain, HMD112. Note:The direction 'NW-SE' described in the pictures is not a real orientation. The upper points to north so as to read easily,

$190 \times 152 \mathrm{~mm}(300 \times 300 \mathrm{DPI})$ 

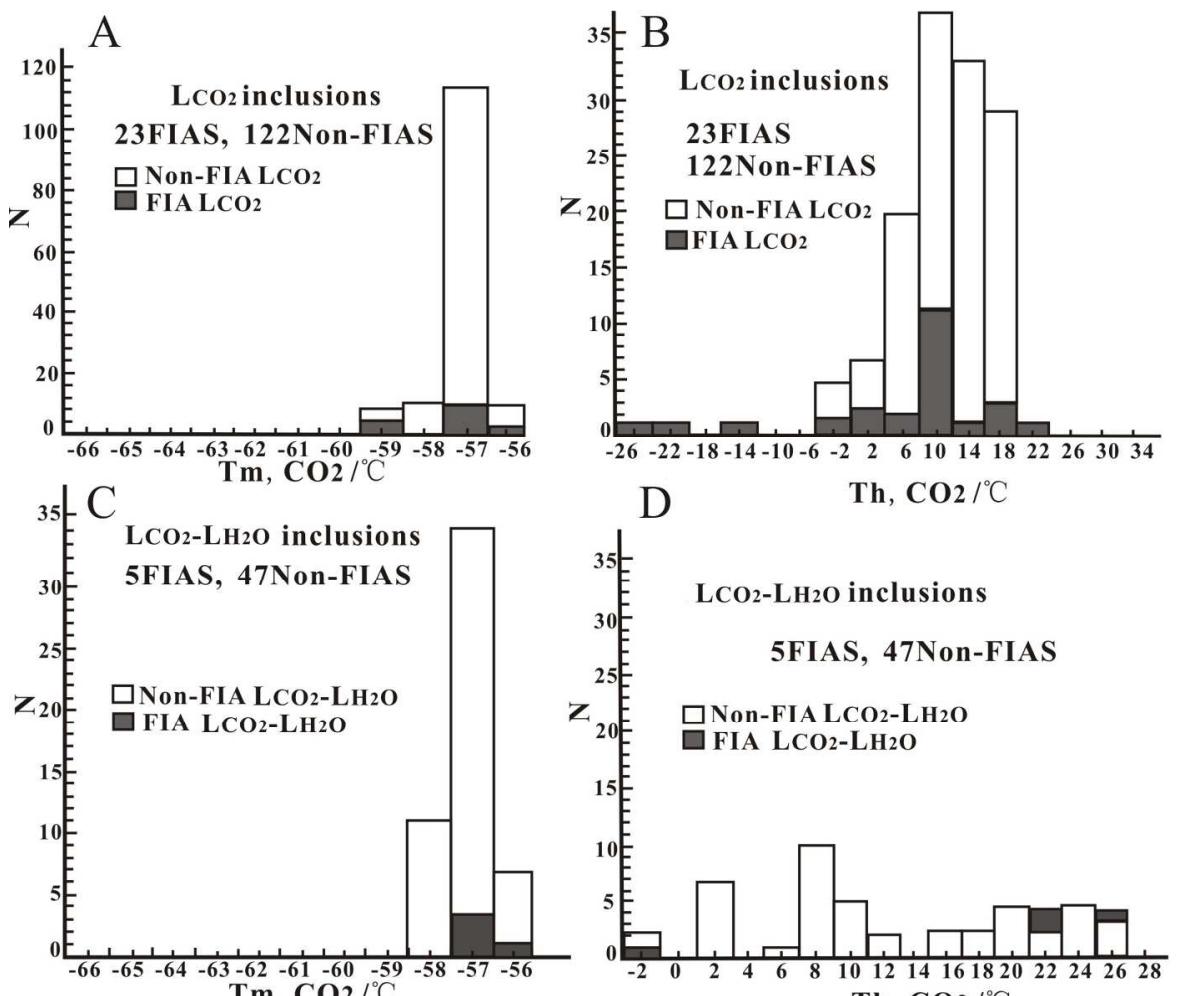

$\mathrm{D}$

$\mathrm{Th}, \mathrm{CO} 2 /{ }^{\circ} \mathrm{C}$
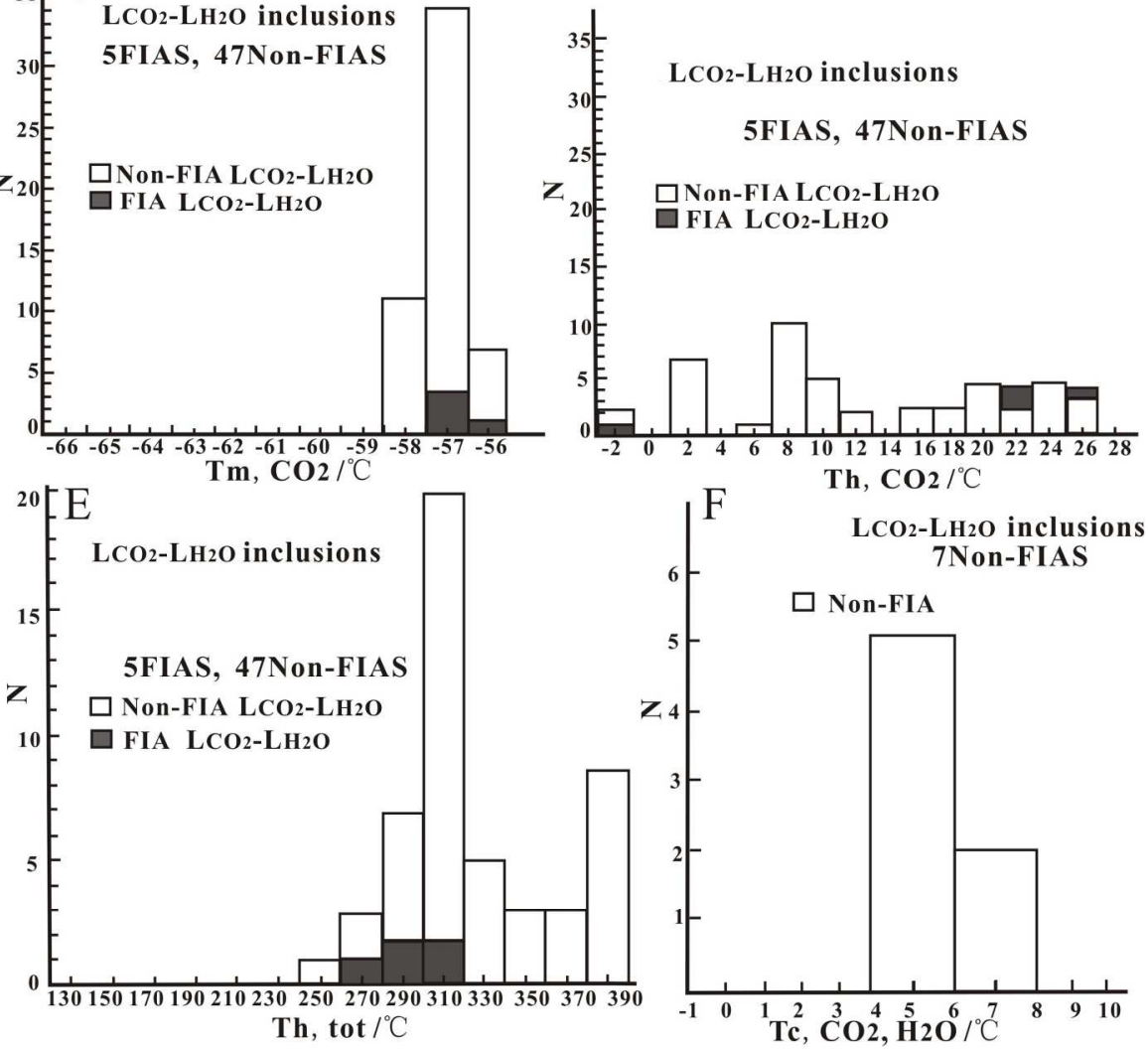

Fig.7 Histograms showing solid $\mathrm{CO} 2$ melting temperatures $(\mathrm{Tm}, \mathrm{CO} 2), \mathrm{CO} 2$ homogenization temperatures (Th, CO2) and final homogenization temperatures (Th,tot) for FIA and non-FIA carbonic (C type) and CO2$\mathrm{H} 2 \mathrm{O}$ inclusions (CW type) in the Hamadi deposit. Note: the temperature value used for FIAs is average of each FIA, not every inclusion, e.g., type carbonic fluid inclusions within a single FIA have a very narrow ranges of $\mathrm{Tm}, \mathrm{CO} 2$ and $\mathrm{Th}, \mathrm{CO} 2$, such as from -56.7 to $-57.0^{\circ} \mathrm{C}(\mathrm{Tm}, \mathrm{CO} 2)$ and from 3.2 to $4.0^{\circ} \mathrm{C}(\mathrm{Th}, \mathrm{CO} 2$ homogenized to liquid $\mathrm{CO} 2$ phase) in sample HMD201.

$177 \times 237 \mathrm{~mm}(300 \times 300$ DPI $)$ 

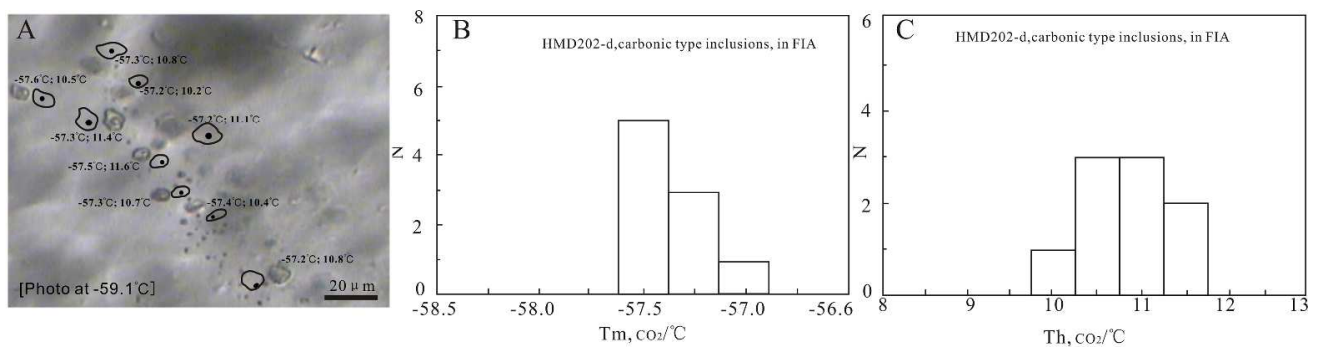

Fig. 8 An example of thermometry data for a carbonic fluid inclusion assemblage (FIA)

(A) Carbonic inclusions occurring as clusters (FIA) in a quartz grain (Sample HMD202-d); (B) Histograms of the melting temperatures of solid $\mathrm{CO} 2(\mathrm{Tm}, \mathrm{CO} 2) ;(\mathrm{C})$ Homogenization temperatures (Th, $\mathrm{CO} 2$, to liquid $\mathrm{CO} 2)$ within the FIA

$519 \times 134 \mathrm{~mm}(300 \times 300$ DPI $)$ 

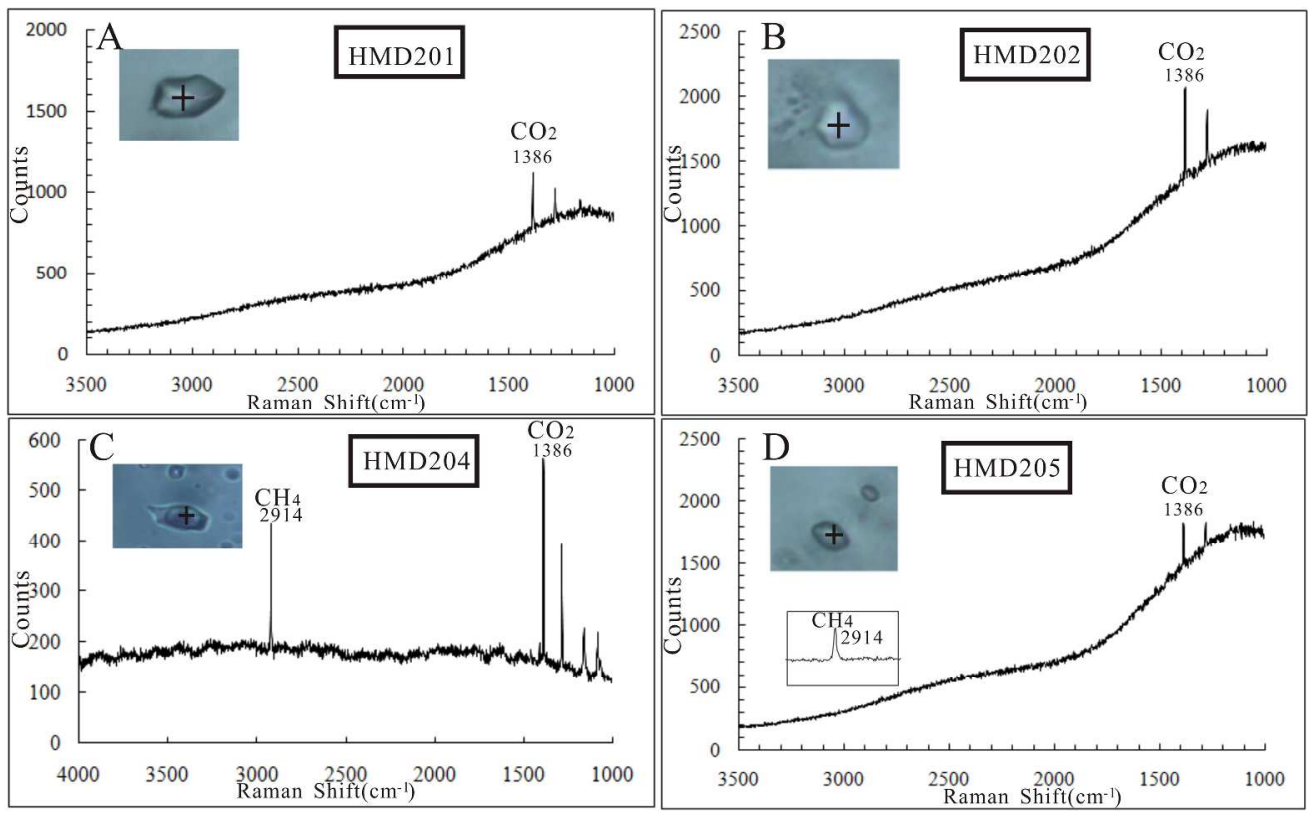

Fig. 9 Laser Raman Microspectra of carbonic fluid inclusions

(A) $\mathrm{CH} 4-$ and $\mathrm{CO} 2$-spectrum of single phase in carbonic fluid inclusion, $\mathrm{HMD} 201$; (B) $\mathrm{CH} 4-$ and CO2spectrum of single phase in carbonic fluid inclusion,HMD202; (C) N2-CH4- and CO2-spectrum of vapor-liquid two phase in fluid inclusion, $\mathrm{HMD} 204$; (D) $\mathrm{CH} 4-$ and $\mathrm{CO} 2$-spectrum of single phase in carbonic fluid inclusion, HMD205.

$417 \times 257 \mathrm{~mm}(300 \times 300$ DPI $)$ 


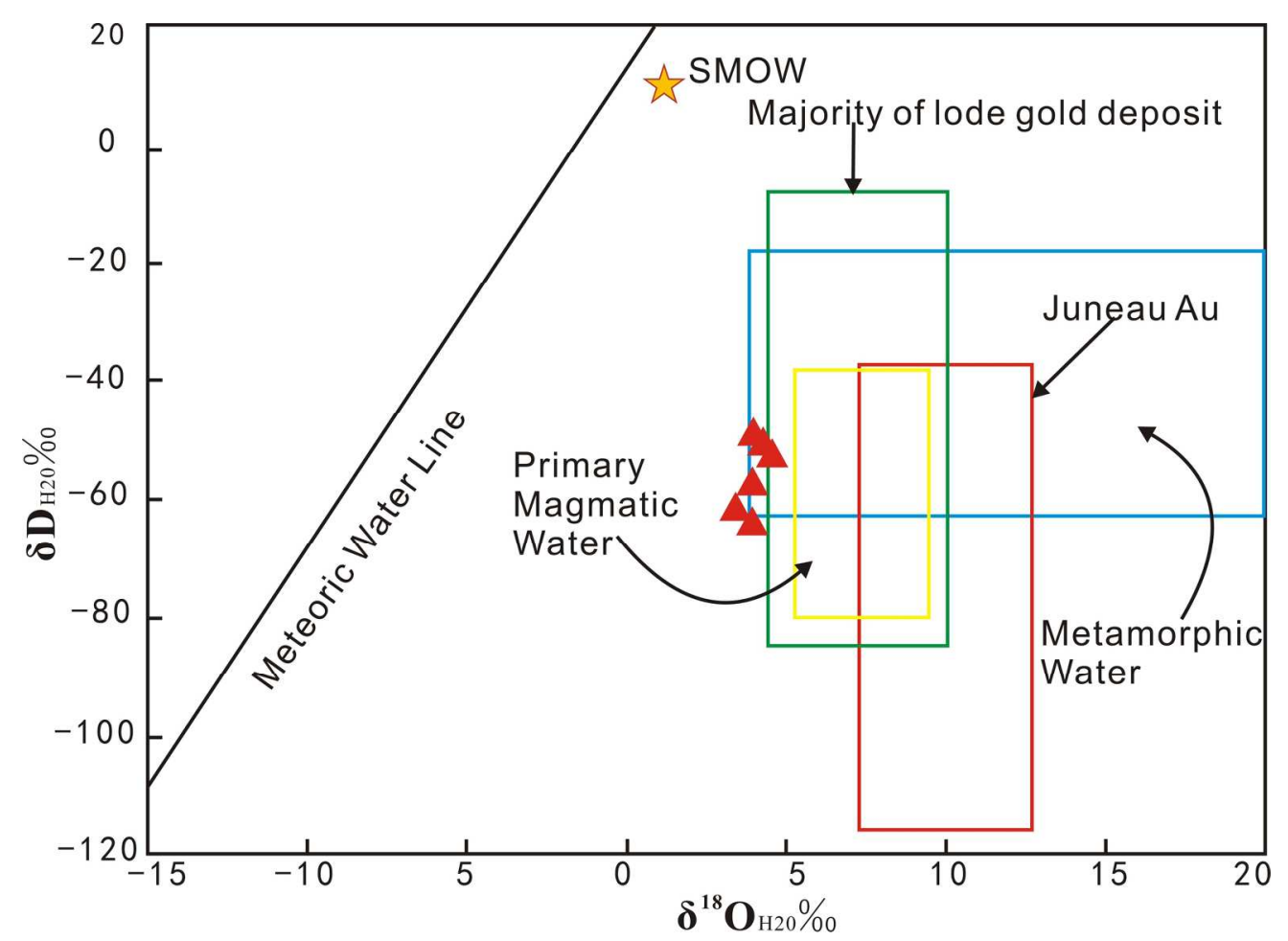

Fig. $10 \delta 180 \mathrm{H} 2 \mathrm{O}-\delta \mathrm{DH} 2 \mathrm{O}$ plots of the ore fluids at the Hamadi gold deposit. Domains for metamorphic and magmatic fluids are cited from Taylor (1997). The field for the Juneau gold belts revised after Goldfarb et al. (1991). The field for Majority of lode gold deposits revised after Goldfarb et al. (2004).

$$
183 \times 133 \mathrm{~mm}(300 \times 300 \mathrm{DPI})
$$




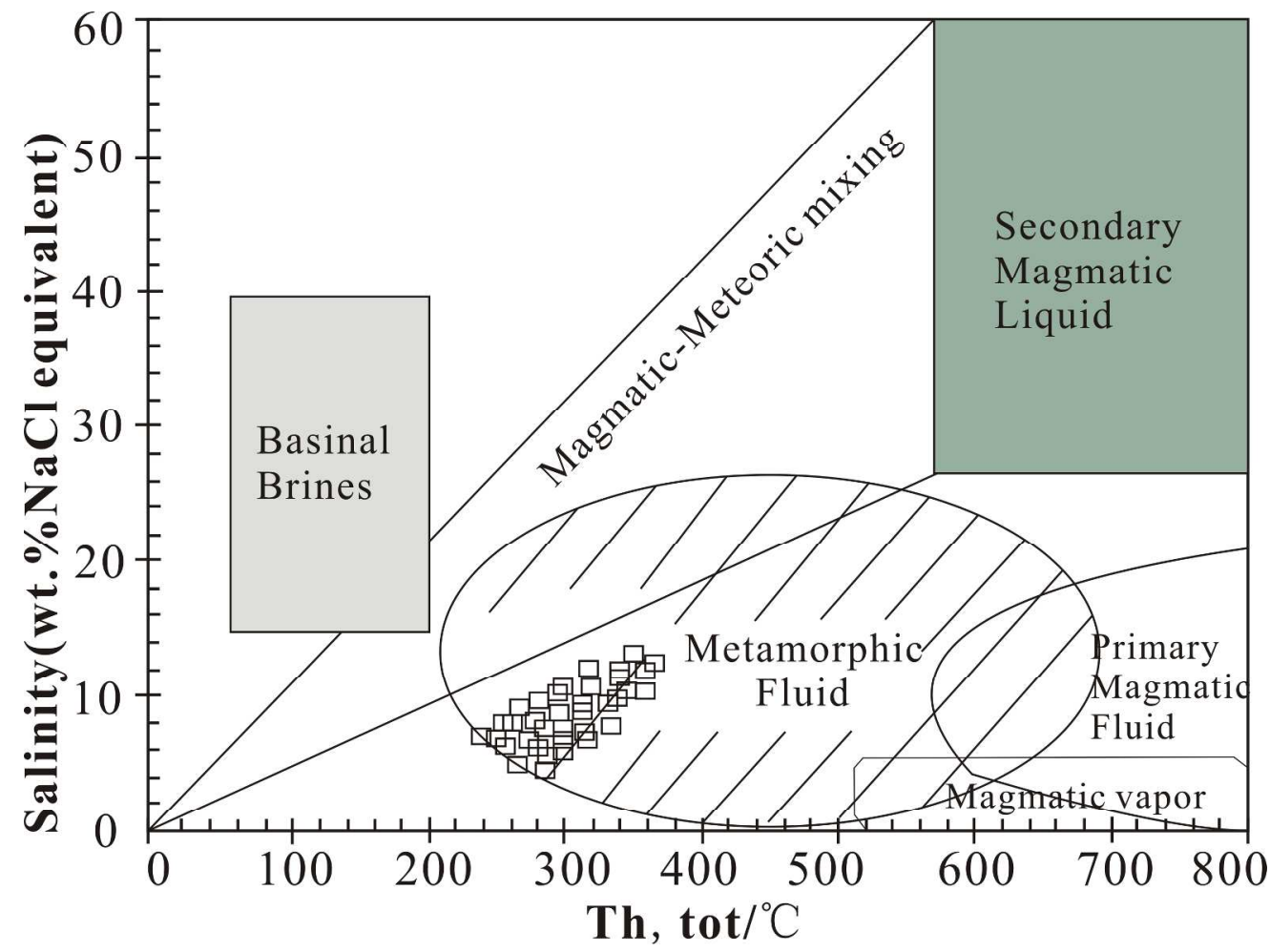

Fig. 11 Homogenization temperature versus salinity diagram for fluid inclusions in Hamadi gold deposit. Fields for various fluid types after Beane (1983). 


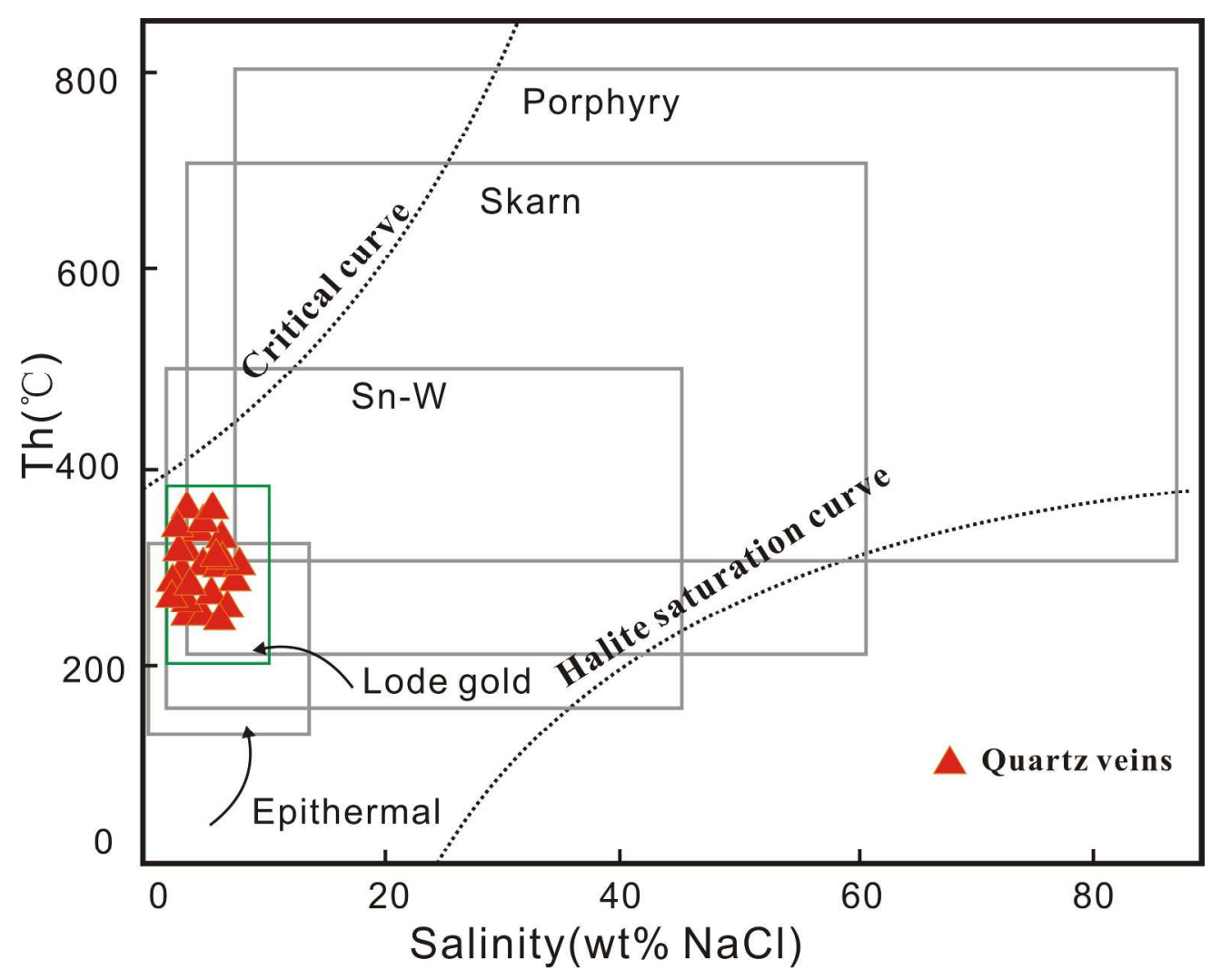

Fig. 12 Homogenization temperatures versus salinities diagram. After Wilkinson (2001). $232 \times 186 \mathrm{~mm}(300 \times 300$ DPI $)$ 


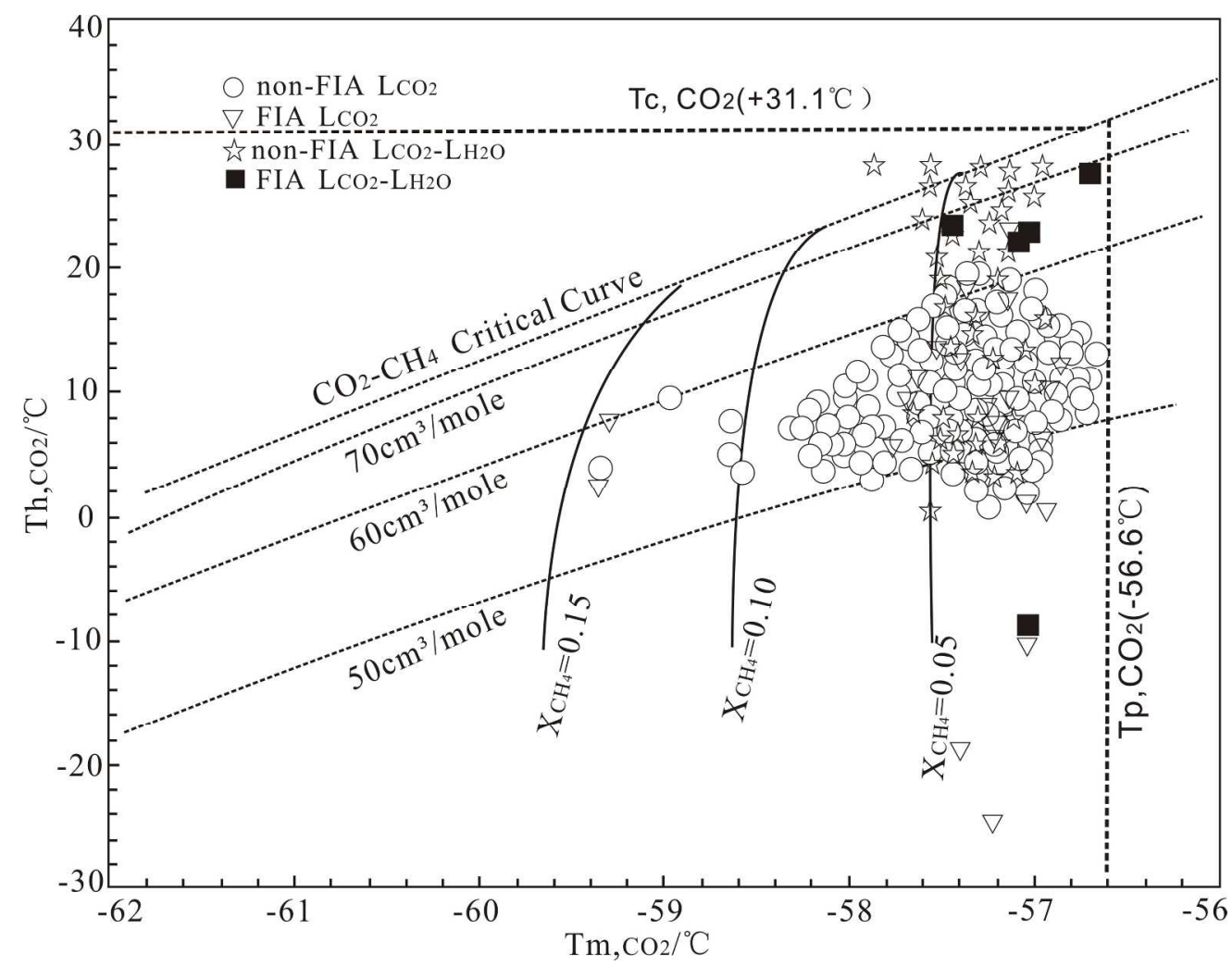

Fig. $13 \mathrm{Tm}, \mathrm{CO} 2-\mathrm{Th}, \mathrm{CO} 2$ of carbonic inclusions and carbonic phase in $\mathrm{H} 2 \mathrm{O}-\mathrm{CO} 2$ inclusions(drawing after van den Kerkhof and Thiéry, 2001 and Thiéry et al., 1994)

$235 \times 185 \mathrm{~mm}(300 \times 300$ DPI $)$ 


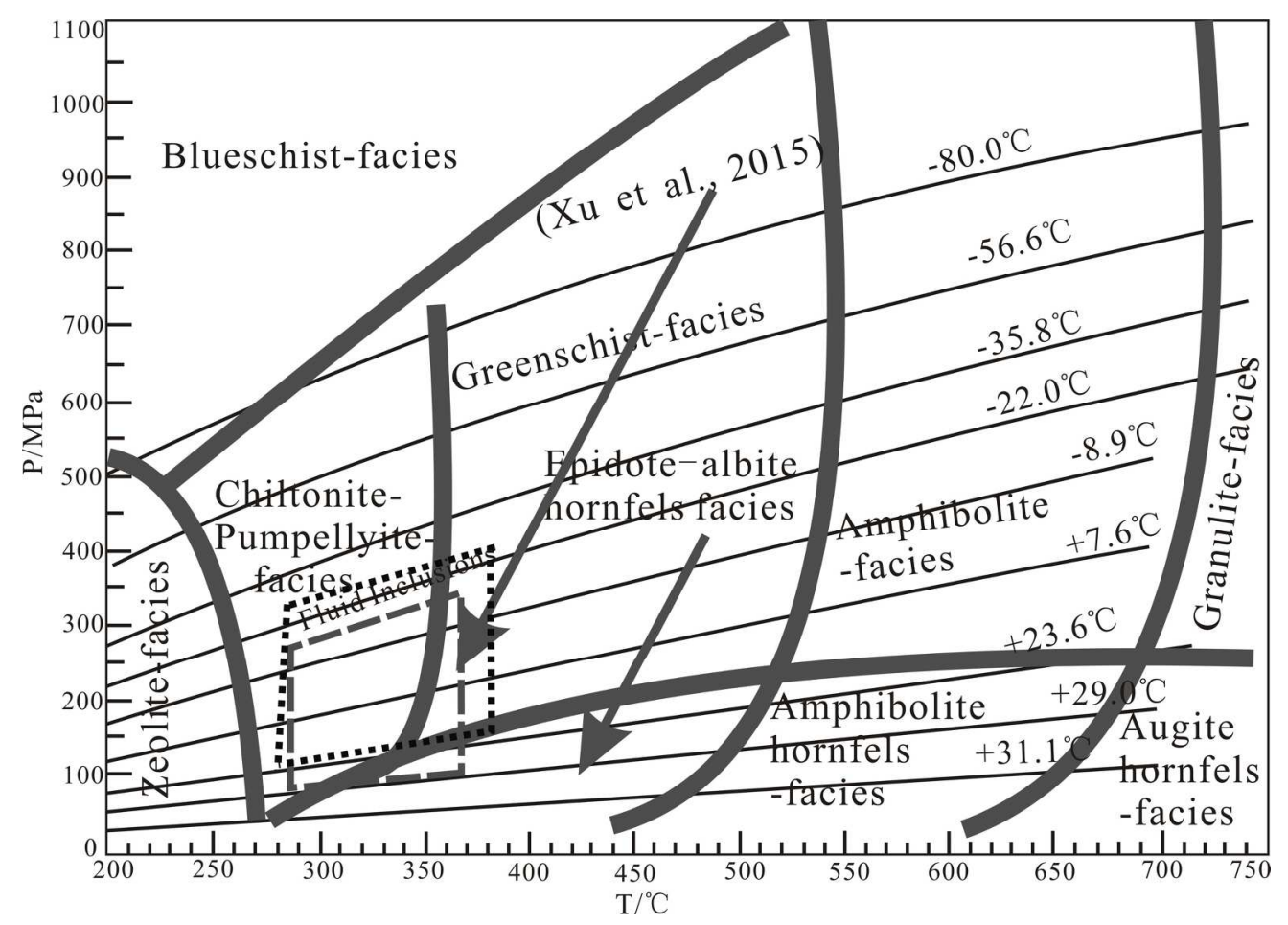

Fig. 14 Trapping P-T conditions of carbonic fluid inclusions at the Hamadi gold deposit (phase diagram after Winter, 2001)

$195 \times 139 \mathrm{~mm}(300 \times 300 \mathrm{DPI})$ 
Table 1 Microthermometric data of fluid inclusions occurring in FIAs from vein quartz in the Hamadi gold deposit

\begin{tabular}{|c|c|c|c|c|c|c|c|c|c|}
\hline Sample & $\begin{array}{c}\text { Sample } \\
\text { Characteristic }\end{array}$ & Occurrance & $\begin{array}{c}\text { Type of } \\
\text { inclusions }\end{array}$ & $\begin{array}{l}\text { Size } \\
(\mu \mathrm{m})\end{array}$ & $\begin{array}{c}\mathrm{Tm}, \mathrm{CO} 2(\square) \\
\text { Range(Number); } \\
\text { Average }\end{array}$ & $\begin{array}{c}\text { Th, } \mathrm{CO} \text { (园) } \\
\text { Range(Number); } \\
\text { Average }\end{array}$ & $\begin{array}{c}\text { Th,total,(圆) } \\
\text { Range(Number); } \\
\text { Average }\end{array}$ & $\rho / g \cdot c m-3$ & $\mathrm{XCH}_{4}$ \\
\hline \multirow{7}{*}{ HMD201 } & \multirow{14}{*}{$\begin{array}{l}\text { quartz vein, } \\
\text { containing calcite } \\
\text { and pyrite, } \\
\text { carbonic fluid } \\
\text { inclusions } \\
\text { distributed in the } \\
\text { healed cracks of } \\
\text { quartz grains }\end{array}$} & FIA & $\mathrm{C}$ & $5 \sim 6$ & $\begin{array}{c}-57.0 \sim-56.7(7) \\
-56.8\end{array}$ & $\begin{array}{c}3.2 \sim 4.0(7) \mathrm{L} \\
3.7\end{array}$ & & 0.88 & 0.013 \\
\hline & & FIA & $\mathrm{C}$ & $3 \sim 4$ & $\begin{array}{c}-57.2 \sim-57.0(3) \\
-57.1\end{array}$ & $\begin{array}{c}-2.2 \sim-1.9(3) \mathrm{L} ; \\
-2.0\end{array}$ & & 0.92 & 0.012 \\
\hline & & FIA & $\mathrm{C}$ & $2 \sim 4$ & $\begin{array}{c}-57.4 \sim-57.0(7) \\
-57.1\end{array}$ & $\begin{array}{c}-18.0 \sim-19.8(7) \\
L ;-18.8\end{array}$ & & 1.01 & 0.019 \\
\hline & & FIA & $\mathrm{C}$ & $4 \sim 10$ & $\begin{array}{c}-57.6 \sim-56.9(6) \\
-57.2\end{array}$ & $\begin{array}{c}-28.3 \sim-26.8(6) \\
L ;-27.4\end{array}$ & & 1.03 & 0.021 \\
\hline & & FIA & $\mathrm{CW}$ & $4 \sim 9$ & $\begin{array}{c}-57.5 \sim-57.1(4) \\
-57.2\end{array}$ & $\begin{array}{c}20.3 \sim 21.2(4) \mathrm{L} ; \\
20.8\end{array}$ & $\begin{array}{c}270 \sim 302(4) \mathrm{L} ; \\
283\end{array}$ & & \\
\hline & & FIA & $\mathrm{CW}$ & $4 \sim 5$ & $\begin{array}{c}-57.2 \sim-57.0(6) \\
-57.1\end{array}$ & $\begin{array}{c}-10.1 \sim-9.0(6) \mathrm{L} ; \\
-9.5\end{array}$ & $\begin{array}{c}292 \sim 303(6) \mathrm{L} ; \\
297\end{array}$ & & \\
\hline & & FIA & $\mathrm{CW}$ & $7 \sim 13$ & $\begin{array}{c}-57.2 \sim-57.0(5) \\
-57.1\end{array}$ & $\begin{array}{c}26.7 \sim 27.8(5) \mathrm{L} ; \\
27.2\end{array}$ & $\begin{array}{c}296 \sim 305(6) \mathrm{L} ; \\
301\end{array}$ & & \\
\hline \multirow{7}{*}{ HMD202 } & & FIA & $\mathrm{C}$ & $4 \sim 5$ & $\begin{array}{c}-57.5 \sim \\
-57.1(10) ;-57.3\end{array}$ & $\begin{array}{l}10.4 \sim 11.6(10) \\
\mathrm{L} ; 10.9\end{array}$ & & 0.84 & 0.021 \\
\hline & & FIA & $\mathrm{C}$ & $3 \sim 12$ & $\begin{array}{c}-57.1 \sim-56.8(7) \\
-56.9\end{array}$ & $\begin{array}{c}-3.3 \sim-1.8(7) \mathrm{L} ; \\
-2.5\end{array}$ & & 0.91 & 0.013 \\
\hline & & FIA & $\mathrm{C}$ & $4 \sim 6$ & $\begin{array}{c}-57.4 \sim-57.1(6) \\
-57.2\end{array}$ & $\begin{array}{c}10.0 \sim 13.8(6) \mathrm{L} \\
12.0\end{array}$ & & 0.82 & 0.016 \\
\hline & & FIA & $\mathrm{C}$ & $5 \sim 8$ & $\begin{array}{c}-57.5 \sim-57.3(7) \\
-57.4\end{array}$ & $\begin{array}{c}18.1 \sim 19.6(7) \mathrm{L} ; \\
18.8\end{array}$ & & 0.76 & 0.023 \\
\hline & & FIA & $\mathrm{C}$ & $4 \sim 10$ & $\begin{array}{c}-57.4 \sim-57.9(5) \\
-57.7\end{array}$ & $\begin{array}{c}2.8 \sim 3.8(5) \mathrm{L} ; \\
3.4\end{array}$ & & \multirow[t]{3}{*}{0.87} & \multirow[t]{3}{*}{0.037} \\
\hline & & FIA & $\mathrm{CW}$ & $5 \sim 13$ & $\begin{array}{c}-57.4 \sim-57.0(5) \\
-57.2\end{array}$ & $\begin{array}{c}23.4 \sim 24.8(5) \mathrm{L} \\
24.0\end{array}$ & $\begin{array}{c}270 \sim 284(6) \mathrm{L} ; \\
279\end{array}$ & & \\
\hline & & FIA & $\mathrm{CW}$ & $6 \sim 10$ & $\begin{array}{c}-57.9 \sim-57.6(6) \\
-57.7\end{array}$ & $\begin{array}{c}18.7 \sim 19.3(6) \mathrm{L} \\
19.1\end{array}$ & $\begin{array}{c}280 \sim 289(6) \mathrm{L} ; \\
281\end{array}$ & & \\
\hline
\end{tabular}




\begin{tabular}{|c|c|c|c|c|c|c|c|}
\hline \multirow{4}{*}{ HMD203 } & FIA & $\mathrm{C}$ & $4 \sim 9$ & $\begin{array}{c}-57.9 \sim-57.4(8) \\
-57.3\end{array}$ & $\begin{array}{c}\text { 8.7 9.6(8) L; } \\
9.1\end{array}$ & 0.83 & 0.034 \\
\hline & FIA & $\mathrm{C}$ & $3 \sim 7$ & $\begin{array}{c}-58.3 \sim-57.6(8) \\
-57.9\end{array}$ & $\begin{array}{c}\text { 7.8 8.6(8) L; } \\
8.3\end{array}$ & 0.84 & 0.042 \\
\hline & FIA & $\mathrm{C}$ & $3 \sim 8$ & $\begin{array}{c}-57.6 \sim-57.4(10) \\
-57.4\end{array}$ & $\begin{array}{c}9.9 \sim 12.2(10) \mathrm{L} ; \\
11.5\end{array}$ & 0.83 & 0.028 \\
\hline & FIA & $\mathrm{C}$ & $2 \sim 6$ & $\begin{array}{c}-57.3 \sim-57.1(9) \\
-57.2\end{array}$ & $\begin{array}{c}11.7 \sim 12.3(9) \mathrm{L} ; \\
11.9\end{array}$ & 0.83 & 0.019 \\
\hline \multirow{4}{*}{ HMD204 } & FIA & $\mathrm{C}$ & $3 \sim 8$ & $\begin{array}{c}-57.6 \sim-57.4(8) \\
-57.4\end{array}$ & $\begin{array}{c}22.9 \sim 24.2(8) \mathrm{L} ; \\
23.7\end{array}$ & 0.71 & 0.025 \\
\hline & FIA & $\mathrm{C}$ & $4 \sim 6$ & $\begin{array}{c}-57.9 \sim-57.8(5) \\
-57.8\end{array}$ & $\begin{array}{c}13.8 \sim 14.5(5) \mathrm{L} ; \\
14.1\end{array}$ & 0.77 & 0.039 \\
\hline & FIA & $\mathrm{C}$ & $5 \sim 8$ & $\begin{array}{c}-60.3 \sim-59.2(10) \\
-59.6\end{array}$ & $\begin{array}{c}\text { 7.9 8.9(10) L; } \\
8.4\end{array}$ & 0.81 & 0.097 \\
\hline & FIA & $\mathrm{C}$ & $3 \sim 7$ & $\begin{array}{c}-57.6 \sim-57.2(7) \\
-57.4\end{array}$ & $\begin{array}{c}18.5 \sim 19.8(7) \mathrm{L} ; \\
19.1\end{array}$ & 0.75 & 0.026 \\
\hline \multirow{6}{*}{ HMD205 } & FIA & $\mathrm{C}$ & $4 \sim 8$ & $\begin{array}{c}-57.6 \sim-57.2(8) \\
-57.4\end{array}$ & $\begin{array}{c}9.4 \sim 10.5(8) \mathrm{L} \\
9.8\end{array}$ & 0.85 & 0.023 \\
\hline & FIA & $\mathrm{C}$ & $3 \sim 6$ & $\begin{array}{c}-58.1 \sim-57.6(7) \\
-57.8\end{array}$ & $\begin{array}{c}9.5 \sim 10.9(7) \mathrm{L} \\
10.1\end{array}$ & 0.82 & 0.036 \\
\hline & FIA & $\mathrm{C}$ & $3 \sim 5$ & $\begin{array}{c}-57.5 \sim-57.2(10) \\
-57.3\end{array}$ & $\begin{array}{c}5.2 \sim 6.4(10) \mathrm{L} \\
5.8\end{array}$ & 0.86 & 0.025 \\
\hline & FIA & $\mathrm{C}$ & $5 \sim 9$ & $\begin{array}{c}-57.3 \sim-56.9(6) \\
-57.1\end{array}$ & $\begin{array}{c}8.2 \sim 9.4(6) \mathrm{L} \\
8.9\end{array}$ & 0.82 & 0.018 \\
\hline & FIA & $\mathrm{C}$ & $4 \sim 10$ & $\begin{array}{c}-57.8 \sim-57.3(7) \\
-57.5\end{array}$ & $\begin{array}{c}9.2 \sim 10.5(7) \mathrm{L} \\
9.8\end{array}$ & 0.84 & 0.022 \\
\hline & FIA & $\mathrm{C}$ & $3 \sim 7$ & $\begin{array}{c}-57.2 \sim-56.9(10) \\
-57.0\end{array}$ & $\begin{array}{c}11.7 \sim 12.8(10) \\
\mathrm{L} ; 12.3\end{array}$ & 0.84 & 0.005 \\
\hline
\end{tabular}

Note: 1) numbers in brackets are fluid inclusions measured. L-homogenized in liquid, V-homogenized in gas; 2) $\mathrm{T}_{\mathrm{h}}$ : homogenization temperature, $\mathrm{T}_{\mathrm{h}}, \mathrm{CO2}$ : CO2 partial homogenization temperatur, $\mathrm{T}_{\mathrm{m}}$ : melting temperature of solid $\mathrm{CO}_{2}$ 
Table 2 Microthermometric data of fluid inclusions occurring in Non-FIAs from vein quartz in the Hamadi gold deposit

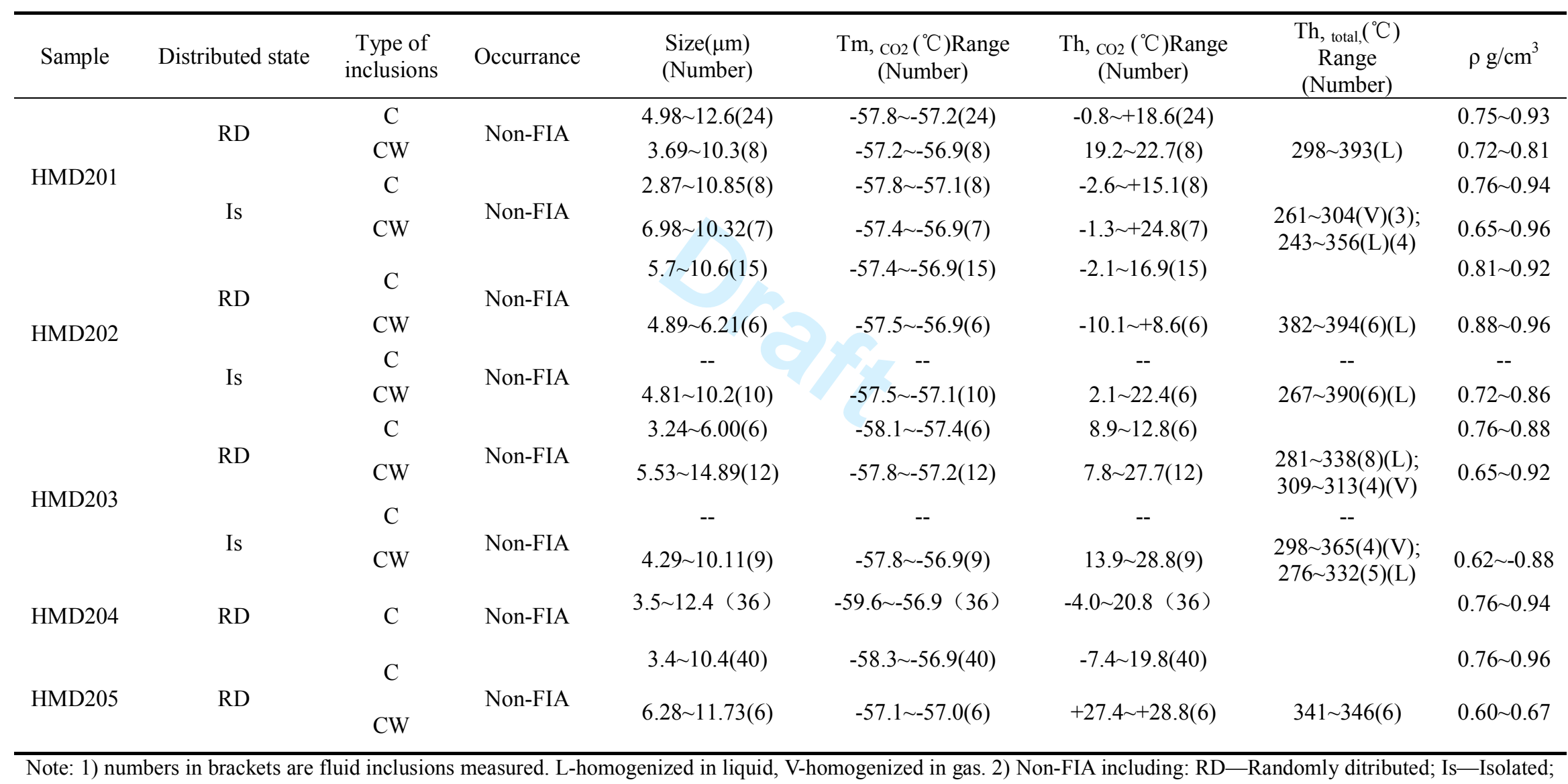

--: No data 
Table 3 Comprehensive thermometry of fluid inclusions in quartz veinlets from gold-bearing altered rocks of the the Hamadi gold deposit

\begin{tabular}{|c|c|c|c|c|c|c|c|c|}
\hline $\begin{array}{l}\text { Sample } \\
\text { Number }\end{array}$ & $\begin{array}{c}\text { Characteristics of } \\
\text { samples }\end{array}$ & Type of inclusions & Size $/ \mu \mathrm{m}$ & $\mathrm{T}_{\mathrm{m}, \mathrm{CO} 2 /]}$ & $\mathrm{T}_{\mathrm{h}, \mathrm{CO} 2 / \text { ] }}$ & $\mathrm{T}_{\mathrm{h}, \mathrm{TOT}} /$ /? & $\overline{\mathrm{X}_{\mathrm{CH} 4}}$ & $\rho / \mathrm{g} \cdot \mathrm{cm}^{-3}$ \\
\hline HMD112 & $\begin{array}{l}\text { Pyrite-quartz veinlets } \\
\text { in carbonificatic }\end{array}$ & $\begin{array}{c}\mathrm{C}, \text { most } \\
\mathrm{CW} \text {, rarely }\end{array}$ & $3 \sim 10$ & $-57.4 \sim-57.1(20)$ & $\begin{array}{c}-19 \sim-12.7(3) ; \\
+7.3 \sim+15.8(16) \\
+14.5 \sim+27.8(14)\end{array}$ & $287 \sim 305(13)$ & $0.015 \sim 0.028$ & $0.78 \sim 1.00$ \\
\hline HMD113 & $\begin{array}{l}\text { Pyrite-quartz veinlets } \\
\text { in altered rocks }\end{array}$ & $\begin{array}{c}\text { C } \\
\text { abundance }\end{array}$ & $2 \sim 20$ & $-58.3 \sim-57.0(40)$ & $\begin{array}{c}-6.8 \sim-0.2(21, \mathrm{~L}) \\
+12.1 \sim+28.9(14, \mathrm{~L})\end{array}$ & & $0.02 \sim 0.06$ & $0.73 \sim 0.94$ \\
\hline HMD115 & $\begin{array}{l}\text { Quartz veinlets in } \\
\text { mylonite chlorite } \\
\text { quartz schist }\end{array}$ & $\begin{array}{c}\mathrm{CW} \\
\text { Very rarely }\end{array}$ & $4 \sim 15$ & $-57.9 \sim-56.8(4)$ & $\begin{array}{c}-8.3 \sim-8.3(2) \\
+0.4 \sim+22.3(8, \mathrm{~L}) \\
+30(1, \mathrm{~V}) \\
+26.7 \sim+28.7(4)\end{array}$ & $339 \sim 363(5)$ & $0.03 \sim 0.04$ & $0.70 \sim 0.95$ \\
\hline HMD116 & $\begin{array}{l}\text { Pyrite-calcite-quartz } \\
\text { veinlets in altered } \\
\text { rocks }\end{array}$ & $\begin{array}{l}\mathrm{C}, \text { most } \\
\mathrm{CW} \text {, rarely }\end{array}$ & $\begin{array}{l}3 \sim 12 \\
3 \sim 9\end{array}$ & $\begin{array}{l}-58.4 \sim-57.0(15) \\
-58.5 \sim-57.5(16)\end{array}$ & $\begin{array}{l}-11.0(1, \mathrm{C}) ;+1.1 \sim \\
\quad+17.1(15, \mathrm{~L}) \\
+26.5 \sim+28.7(16)\end{array}$ & $341 \sim 346(16)$ & $0.01 \sim 0.07$ & $0.73 \sim 0.88$ \\
\hline
\end{tabular}

Note: 1) The numbers in brackets represent inclusion numbers; 2) L-Homogenized into liquid $\mathrm{CO}_{2}$, V- Homogenized into gas $\mathrm{CO}_{2}$, $\mathrm{C}$ - $\mathrm{Homogenized} \mathrm{into} \mathrm{critical}$

point 
Table 4 Comparisons of major characteristics of the Hamadi gold deposit and other deposit by $\mathrm{H}_{2} \mathrm{O}$-poor, $\mathrm{CO}_{2}$-dominated fluids

\begin{tabular}{|c|c|c|c|c|c|c|c|c|c|}
\hline Location & Deposit & FIs type & $\mathrm{Size} / \mu \mathrm{m}$ & $\mathrm{T}_{\mathrm{m}, \mathrm{CO} 2} /{ }^{\circ} \mathrm{C}$ & $\mathrm{Th}, \mathrm{CO}_{2} /{ }^{\circ} \mathrm{C}$ & $\mathrm{T}_{\mathrm{h}, \mathrm{TOT}} /{ }^{\circ} \mathrm{C}$ & $\rho / \mathrm{g} \cdot \mathrm{cm}^{-3}$ & $\begin{array}{c}\mathrm{P}-\mathrm{T} \\
\text { condition }\end{array}$ & References \\
\hline Xijiang, China & $\begin{array}{l}\text { Sarekuobu gold } \\
\text { deposit }\end{array}$ & $\begin{array}{l}\mathrm{L}_{\mathrm{CO} 2} \\
\text { abundance }\end{array}$ & $2.8 \sim 12.1$ & $-78.1 \sim-61.9$ & $-33.7 \sim-17.7$ & $254 \sim 276$ & $0.74 \sim 1.02$ & $\begin{array}{l}150 \sim 320 \\
\mathrm{MPa} ; 250 \sim 280\end{array}$ & $\begin{array}{l}\mathrm{Xu} \text { et al. } \\
2005\end{array}$ \\
\hline $\begin{array}{l}\text { Muruntau, } \\
\text { Uzbekistan }\end{array}$ & Muruntau gold deposit & $\begin{array}{l}\mathrm{L}_{\mathrm{CO} 2-\mathrm{CH} 4} \\
\text { abundance }\end{array}$ & $5.5 \sim 20$ & $-65 \sim-58.6$ & $-27.5 \sim+27.8$ & & $0.56 \sim 1.00$ & & $\begin{array}{l}\mathrm{Xu} \text { et al. } \\
2007\end{array}$ \\
\hline $\begin{array}{l}\text { Campbell-RedLake, } \\
\text { Canada }\end{array}$ & $\begin{array}{l}\text { Campbell-Red Lake } \\
\text { gold deposit }\end{array}$ & $\begin{array}{l}\mathrm{L}_{\mathrm{CO} 2} \\
\text { abundance }\end{array}$ & $3 \sim 26$ & $-59.2 \sim-56.7$ & $-5 \sim+31$ & $250 \sim 390$ & & & $\begin{array}{l}\text { Chi et al. } \\
2006\end{array}$ \\
\hline $\begin{array}{l}\text { Ipitinga } \\
\text { Auriferous,northern Brazil }\end{array}$ & Carará gold deposit & $\begin{array}{l}\mathrm{L}_{\mathrm{CO} 2} \\
\text { abundance }\end{array}$ & $5 \sim 15$ & $-58.2 \sim-56.6$ & $-28.5 \sim+29.9$ & $350 \sim 475$ & $0.89 \sim 1.07$ & $180 \sim 360 \mathrm{MPa}$ & $\begin{array}{l}\text { Evandro } \\
\text { and Kazuo } \\
2010\end{array}$ \\
\hline Ashanti Belt, Ghana & $\begin{array}{l}\text { gold deposits in the } \\
\text { Ashanti Belt }\end{array}$ & $\begin{array}{l}\mathrm{L}_{\mathrm{CO} 2} \\
\text { abundance }\end{array}$ & $6 \sim 17$ & $-57.1 \sim-61.4$ & $-15 \sim-9.8$ & $150 \sim 440$ & $0.89 \sim 0.99$ & $170 \sim 540 \mathrm{MPa}$ & $\begin{array}{l}\text { Mummá et } \\
\text { al. } 1997\end{array}$ \\
\hline $\begin{array}{l}\text { Hamadi, } \\
\text { North Sudan }\end{array}$ & Hamadi gold deposit & $\begin{array}{l}\mathrm{L}_{\mathrm{CO} 2} \\
\text { abundance }\end{array}$ & $3-15$ & $-59.6 \sim-56.6$ & $-28.3 \sim+24.2$ & $270 \sim 400$ & $0.73 \sim 1.03$ & $\begin{array}{l}270 \sim 400^{\circ} \mathrm{C} \\
100 \sim 400 \mathrm{MPa}\end{array}$ & This study \\
\hline
\end{tabular}


Table 5 Comparisons of major characteristics of the Hamadi gold deposit and orogenic deposits

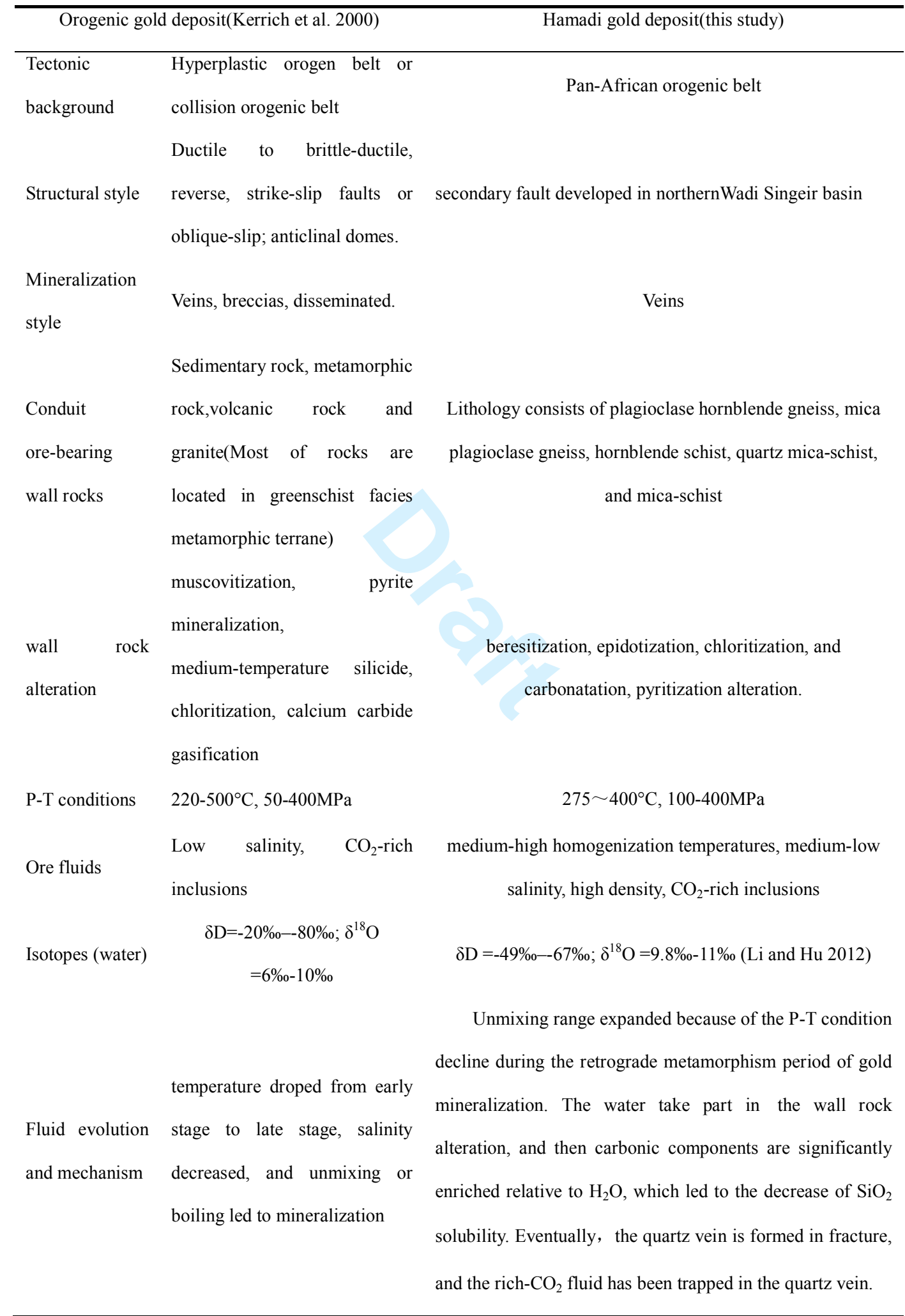




\section{Research Highlights}

I. Carbonic fluid inclusions are dominant both in quartz of gold-bearing veins and altered rocks at the Hamadi gold deposit, Sudan.

II. Carbonic inclusions in the Hamadi gold deposit came from an immiscible aqueous-carbonic mixing fluids during retrogress metamorphism.

III. The formation of Hamadi gold deposit was related with extremely $\mathrm{CO}_{2}$-rich fluids. 